\title{
Will the role of intercontinental transport change in a changing climate?
}

\author{
T. Glotfelty ${ }^{1}$, Y. Zhang ${ }^{1}$, P. Karamchandani ${ }^{2}$, and D. G. Streets ${ }^{3}$ \\ ${ }^{1}$ Department of Marine, Earth, and Atmospheric Sciences, North Carolina State University, Raleigh, NC, USA \\ ${ }^{2}$ ENVIRON International Corporation, Novato, CA, USA \\ ${ }^{3}$ Decision and Information Sciences Division, Argonne National Laboratory, Argonne, IL, USA \\ Correspondence to: Y. Zhang (yang_zhang@ @ ncsu.edu)
}

Received: 25 September 2013 - Published in Atmos. Chem. Phys. Discuss.: 11 October 2013

Revised: 11 July 2014 - Accepted: 28 July 2014 - Published: 10 September 2014

\begin{abstract}
Intercontinental transport of atmospheric pollution (ITAP) can offset the impact of local emission control efforts, impact human and ecosystem health, and play a role in climate forcing. This study aims to determine the role of ITAP caused by East Asian anthropogenic emissions (EAAEs) under current and future emission and climate scenarios. The contribution from EAAEs is determined using a "brute force method" in which results from simulations with and without EAAEs are compared. ITAP from East Asia is enhanced in the future due to faster wind speeds aloft and a stronger low pressure center near eastern Russia that facilitate enhanced westerly export in the free troposphere and stronger southerly transport near the surface, increased gaseous precursor emissions, and increased temperatures. As a result, the contribution of ozone $\left(\mathrm{O}_{3}\right)$ generated by EAAEs to the global average $\mathrm{O}_{3}$ mixing ratio increases by $\sim 0.8 \mathrm{ppb}$ from $1.2 \mathrm{ppb}$ in 2001 to $2.0 \mathrm{ppb}$ in 2050 . The contribution of $\mathrm{PM}_{2.5}$ generated by EAAEs to the global $\mathrm{PM}_{2.5}$ level increases by $\sim 0.07 \mu \mathrm{g} \mathrm{m}^{-3}$

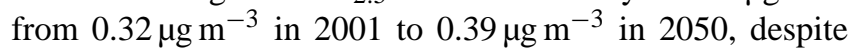
a non-homogenous response in $\mathrm{PM}_{2.5}$ resulting from cloud and radiative feedbacks. EAAEs can increase East Asian biogenic secondary organic aerosol by $10-81 \%$, indicating that it is largely controllable. EAAEs also increase the deposition of nitrogen, black carbon, and mercury both locally and downwind, implying that they may play a role in climate feedbacks and ecosystem health of these regions. These results show that EAAEs have a large impact on global air quality and climate, especially on downwind regions. Such impacts may be enhanced under future climate and emission scenarios, demonstrating a need to synergize global pollution control and climate mitigation efforts.
\end{abstract}

\section{Introduction}

Intercontinental transport of atmospheric pollution (ITAP) is of major concern as it can offset the impact of local emission control efforts in certain regions (Jacob et al., 1999; Lin et. al., 2008; Wang et al., 2009, 2012). ITAP of fine aerosols has also been shown to be a health hazard resulting in an estimated 90000 premature deaths globally in 2000 (Liu et al., 2009). ITAP plays a large role in the Northern Hemisphere (NH), as this is the most populated part of the globe, with three major industrial centers including East Asia, North America, and Europe. East Asia is the most important source region as its lower latitudes and thus higher surface radiation and vertical transport make it more suitable for local ozone $\left(\mathrm{O}_{3}\right)$ photochemical production and transport (Bey et al., 2001; Wild and Akimoto, 2001; Stohl et al., 2002). As a result, the Asian free troposphere has been shown to have a large global impact on the seasonal variations and vertical structure of $\mathrm{O}_{3}$ throughout the troposphere (Sudo and Akimoto, 2007). North America is also an important source of global pollution, but it is the most affected receptor to Asian emissions and to a lesser extent to European emissions (Wild and Akimoto, 2001; Fiore et al., 2009). Europe is typically the weakest source region, as weaker convection and the dominance of high pressure systems in summer make horizontal boundary layer advection the primary transport mechanism. This type of transport is typically blocked by the Eurasian terrain and the pollutants are subject to greater local deposition. However, transport to the Arctic makes Europe the most important contributor to Arctic haze especially in winter (Wild and Akimoto, 2001; Stohl et al., 2002). 
Additionally, Europe is a receptor since East Asia has a large global impact (Wild and Akimoto, 2001).

Transport from East Asia to North America occurs primarily through uplifting associated with the warm conveyor belt of mid-latitude cyclones, which lofts the pollutants into the lower free troposphere (FT) where they are transported by westerly winds (Bey et al., 2001; Husar et al., 2001; Hess et al., 2003; Jaffe et al., 2003; Liu et al., 2003; Cooper et al., 2004; Wang et al., 2009, 2012). Additional transport pathways include planetary boundary layer (PBL) outflow behind cold fronts (Liu et al., 2003; Wang et al., 2009, 2012), orographic uplifting in China (Liu et al., 2003), and strong convection (Liu et al., 2003; Takigawa et al., 2005). This uplift is usually associated with fast transport that can occur in as quickly as 6 days (Jaffe et al., 1999, 2003). Intercontinental transport from North America to Europe has been linked not only to uplift from warm conveyor belts but also to pyroconvection from wild fires (Ravetta et al., 2008). Wang et al. (2009) showed that certain pollutants such as $\mathrm{CO}, \mathrm{O}_{3}$, $\mathrm{PM}_{2.5}$, and $\mathrm{SO}_{4}^{2-}$ favor transport in both the $\mathrm{PBL}$ and lower FT, while other pollutants such as $\mathrm{PAN}, \mathrm{SO}_{2}$, and $\mathrm{NO}_{3}^{-}$primarily transport in the lower FT. Wang et al. (2012) showed that dust particles transport at altitudes above $5 \mathrm{~km}$.

Although it may be counter-intuitive, ITAP plays a much larger role in the boreal spring and autumn months as compared to the summer when production of pollutants such as $\mathrm{O}_{3}$ is higher (Wild and Akimoto, 2001; Shindell et al., 2008; Fiore et al., 2009; Jonson et al., 2010). This is because although convective uplift is greater in the summer, there is more stagnation and thus less significant horizontal transport. Additionally, the lifetime of $\mathrm{O}_{3}$ is relatively shorter in the summer months due to the additional water vapor resulting from greater evaporation. This occurs because (1) there is a greater chance for $\mathrm{O}\left({ }^{1} \mathrm{D}\right)$ to react with $\mathrm{H}_{2} \mathrm{O}$ to form $\mathrm{OH}$ rather than $\mathrm{O}$ which reduces $\mathrm{O}_{3}$ production, and (2) the increased $\mathrm{OH}$ or $\mathrm{HO}_{2}$ from this process can react with $\mathrm{O}_{3}$ directly. The decreased production and increased destruction occur in the remote marine environments and FT, where the mixing ratios of $\mathrm{O}_{3}$ precursors are low and most $\mathrm{O}_{3}$ transport occurs. However, it is important to note that the increased $\mathrm{OH}$ in the terrestrial PBL leads to greater production of $\mathrm{O}_{3}$ from reactions with volatile organic compounds (VOCs) that dominate over its destruction. Thus, transport is most effective in spring as the frequency of uplift from mid-latitude cyclones is high and the westerly transport is more direct (Wild and Akimoto, 2001). However, it can still play a minor role in the summer. For example, it accounts for $3 \%$ of the North American $\mathrm{O}_{3}$ budget (Pfister et al., 2008).

The Task Force on Hemispheric Transport of Air Pollution (HTAP) was formed in 2004 to improve the understanding of ITAP in the NH. The HTAP program included a multimodel ensemble of experiments that compared the impact of $20 \%$ reductions in anthropogenic emissions from their baseline levels in the four largest industrial centers including Eu- rope, North America, East Asia, and South Asia. The aim of these multi-model ensemble experiments was to estimate the sensitivity of each region's ambient pollution to these emission reductions. These studies, along with others, were compiled into the 2010 Task Force on Hemispheric Transport of Air Pollution report (TF-HTAP) (http://www.htap.org/). These experiments found that, during spring months, the $20 \%$ emission reductions largely from Asia can reduce the ozone level by over $1 \mathrm{ppb}$ or greater at Trinidad Head, CA, at the surface and throughout the troposphere (Jonson et al., 2010). These reductions in East Asia emissions typically result in a decrease in the maximum $8 \mathrm{~h} \mathrm{O}_{3}$ mixing ratio (maximum $8 \mathrm{~h} \mathrm{O}_{3}$ ) by $\sim 0.9 \mathrm{ppb}$ regardless of its level in the western US, but its magnitude of decrease varies with the maximum $8 \mathrm{~h} \mathrm{O}_{3}$ level in the eastern US (e.g., decreasing by 0.65 and $0.3 \mathrm{ppb}$ at lower and higher maximum $8 \mathrm{~h} \mathrm{O}_{3}$, respectively) (Reidmiller et al., 2009). The emission reductions of $\mathrm{O}_{3}$ precursors from East Asia were estimated to decrease the annual mortality rate in North America by 200 deaths but could decrease the number of premature deaths by as much as 5900 over the entire NH (Anenberg et al., 2009). The experiments also revealed that long-term responses of surface ozone concentrations to emissions reductions of $\mathrm{CH}_{4}$ are as large as the impact from reducing emissions of nitrogen oxides $\left(\mathrm{NO}_{\mathrm{x}}\right)$, total non-methane VOCs, and CO combined (Fiore et al., 2009). A subset of the HTAP models reveals that projected climate change increases the impact of reducing anthropogenic emissions in source regions but reduces the impact on receptor regions (Doherty et al., 2013). In addition to the impacts on $\mathrm{O}_{3}$, these emission reductions have been shown to decrease the reactive nitrogen deposition in North America by $1.3 \%$ (Sanderson et al., 2008). The HTAP modeling also showed that East Asia contributes 19, 31,29 , and $28 \%$ to the Arctic sulfate, black carbon (BC), $\mathrm{CO}$, and $\mathrm{O}_{3}$, respectively during the spring months. During the summer months when the BC snow albedo feedback is the strongest, $\mathrm{BC}$ deposition from East Asia is important and comparable to that from North America (Shindell et al., 2008).

Other studies have also investigated the impact of longrange transport of East Asian aerosols (Park et al., 2004; Hadley et al., 2007; Koch et al., 2007; Liu et al., 2008; Yu et al., 2008; Leibensperger et al., 2011). It is estimated that $4.4 \mathrm{Tg} \mathrm{a}^{-1}$ of fine aerosol pollution is imported to North America from Asia, which is equivalent to approximately $15 \%$ of local emissions (Yu et al., 2008). This transport contributes $10-30$ and $30-50 \%$ to the background sulfate over the eastern and western US, respectively, and $75 \%$ to the BC over North America (Park et al., 2004; Hadley et al., 2007; Liu et al., 2008). Emissions of other compounds such as $\mathrm{NO}_{\mathrm{x}}$ and $\mathrm{CO}$ in East Asia have also been shown to increase the concentrations of fine particles $\left(\mathrm{PM}_{2.5}\right)$ by $1.0 \mu \mathrm{g} \mathrm{m}^{-3}$ in the eastern US (Leibensperger et al., 2011). Additionally, aerosols emitted from East Asia can have several climatic impacts (Lau et al., 2006a, b; Menon et al., 
2002; Roberts et al., 2006; Qian et al., 2003, 2006, 2007; Zhang et al., 2007). Compared to ultra-fine marine aerosols, long-range transport of anthropogenic particles in stratified layers from 1000 to $7000 \mathrm{~m}$ above the surface of the eastern Pacific has been shown to play a more important role in the aerosol direct and indirect effects as their larger size increases their likelihood of activation and thus effectiveness at scattering radiation (Roberts et al., 2006). Light-absorbing aerosols have been linked to the enhancement of wintertime convection over the North Pacific (Zhang et al., 2007) and to dynamic and thermodynamic feedbacks that can alter the Asian monsoon (Lau et al., 2006a, b). The light-absorbing $\mathrm{BC}$ aerosols emitted in East Asia have also been shown to result in dimming of $1.45-1.47 \mathrm{Wm}^{-2}$ in the western US (Hadley et al., 2007). In China, increasing aerosol emissions provides a plausible explanation for the decreasing solar radiation reaching the surface despite decreasing cloud cover (Qian et al., 2003, 2006, 2007). It has also been shown that areas with high anthropogenic emissions, such as East Asia, can contribute substantially to the formation of local biogenic secondary organic aerosol (BSOA) (Carlton et al., 2010 and references therein).

There are several methods that can be employed to calculate the sensitivity of a chemical species in the atmosphere to transport from a particular source. The simplest method is the so-called "brute force" method in which the sensitivity of atmospheric pollutants can be calculated by comparing two simulations: one with and one without emissions in the area of interest. The advantages of this method are that it is straightforward and it accounts for the full nonlinear effects of chemistry. However, it has been shown that the results from this method are susceptible to model noises, since the contributions from the source regions can be of the same order of magnitude or smaller than differences between the two simulations resulting from model noises in some cases (Brandt et al., 2012). A more complex method is the socalled "tagged tracer" method, where the concentration of a particular species (i.e., a tracer species) in a particular region is modeled and calculated in parallel with the background species concentration. This method is typically applied for a limited number of species and thus does not represent the full nonlinear effects of chemistry with the background concentration; but it works well for species that are tracer-like such as CO (Fischer et al., 2010; Brandt et al., 2012). This method has been recently updated to represent nonlinear effects and is less susceptible to the influence from model noises (Brandt et al., 2012). The most complex method is an adjoint approach. The model is viewed as an operator that acts on various vectors representing the initial concentrations of a particular set of species and a vector representing a set of parameters that correspond to the evolved concentration at a later time. The adjoint model calculates the sensitivity of a scalar model response function based on the given parameters which can correspond to chemical species at a given time or source location (Henze et al., 2009). This approach, however, does not account for the nonlinear effects of chemistry.

This study aims to determine the role of the ITAP from East Asian anthropogenic emissions (EAAEs) in global air quality and climate under current and future emissions and climate scenarios using the "brute force" method (BFM). The BFM is used because its implementation is straightforward and it also accounts for the nonlinear effects of chemistry. Specifically, several science and policy-related questions will be addressed. For example, how will the role of ITAP change under future scenarios? What processes and factors will dominate such changes? How much BSOA can be reduced through reducing EAAEs? Such information would be very useful in guiding the development of future emission control and climate mitigation strategies in a changing climate.

\section{Experimental design}

The model used in this work is the newly developed Globalthrough-Urban Weather Research and Forecasting Model with Chemistry (GU-WRF/Chem) of (Zhang et al., 2012b). This model is an online-coupled meteorology and chemistry model, which enables the simulation of the climate feedbacks associated with aerosols and radiative gases from global to urban scales. It was developed by first replacing the WRF model in the National Oceanic and Atmospheric Association's (NOAA) mesoscale WRF/Chem with the National Center for Atmospheric Research's (NCAR) global WRF (GWRF) and then improving several model treatments for their applications on hemispheric to global scales including online dust and biogenic volatile organic compounds (BVOCs) emissions, gas-phase chemistry, a photolytic rate scheme, aerosol chemistry and microphysics, and aerosolcloud interactions. GWRF and GU-WRF/Chem have been evaluated using meteorological, radiative, and chemical observations from surface networks and satellites. They demonstrate satisfactory performance as compared to other existing global and mesoscale atmospheric models (Zhang et al., 2012a, b).

GU-WRF/Chem simulations are first completed for the full years of 2001, 2010, 2020, 2030, 2040, and 2050 to characterize the trends of climate changes based on an average of current years (AOC), consisting of the years 2001 and 2010 and an average future time period (AOF) consisting of the years 2020, 2030, 2040, and 2050. These results will be presented in a separate paper. The simulations of 2001 and 2010 are performed with two different sets of initial conditions. The first set of simulations is initialized with the climate input data from the same model (i.e., the Community Climate System Model version 3 (CCSM3)) as the future year simulations and is used to illustrate trends in future climate and emissions, while the second set of simulations is initialized with reanalysis data to evaluate whether the model can reproduce the current atmosphere. In this work, the boreal 
spring months (March, April, and May (MAM)) during 2001 and 2050 during which ITAP is the strongest for the transPacific region are selected to study the role of intercontinental transport of East Asian air pollutants and their impacts on the US and global air quality and climate. Additional simulations under different emission and climate scenarios for MAM 2001 and 2050 are conducted and compared to those of the MAM 2001 and 2050 simulations as part of the aforementioned multi-year simulations. The suite of model simulations conducted includes three baseline simulations with EAAEs during MAM: 2001 with current climate conditions and emissions, 2050 with projected climate change and emissions, and 2050 with projected climate change only (referred to as 2001, 2050, and 2050_CCO, respectively), and three sensitivity simulations in which EAAEs are removed in the East Asia region including China, North and South Korea, Japan, and portions of India, Mongolia, Southeast Asia, and Russia. The years 2001 and 2050 were selected as they show the full changes in emissions and climate forcing between the current and near future periods, and additional sensitivity simulations without EAAEs for multiple years would require substantial computational resources that were not available for this study. However, as discussed in Sect. 3, the difference in the model simulations between the individual years (2001 and 2050) and the average of the current and future periods is smaller than the differences between the current and future time periods for several meteorological variables, indicating that the differences between the individual years largely represent changes in climate rather than just differences in model weather between both years, although some degrees of internal model variability will affect the results. Unlike the $20 \%$ reductions of anthropogenic emissions used in HTAP, all Asian anthropogenic emissions are zeroed out in the sensitivity simulations in this work to estimate the maximum possible impacts of EAAEs on global air quality and climate. This will lead to significant nonlinear impacts on $\mathrm{O}_{3}$ and fine particle formation, but accounting for these processes is necessary to quantify the impact that East Asia has on the global chemical/climate system and to understand how this impact will change in response to changing climate and emissions. The anthropogenic emission inventory used for the 2001 simulations is described in Zhang et al. (2012b), and the 2050 emissions are generated using region-wide growth factors for 17 world regions based on the Intergovernmental Panel on Climate Change (IPCC) Forth Assessment Report (AR4) Special Report on Emissions Scenarios (SRES) A1B scenario. The A1B scenario is described by rapid economic and population growth that peaks in the mid twenty first century and declines thereafter, with rapid introduction of new and more efficient technologies and a balance of energy production from multiple sources. The growth factors are developed following the approach of Nakicenovic et al. (2000) and Rijksinstituut voor Volksgezondheid en Milieu (RIVM) (2001) and are provided in Table S1 in the Supplement. Natural emissions of BVOCs, dust, and sea salt are calculated online using the Model of Emissions of Gases and Aerosols from Nature version 2 (MEGAN2) (Guenther et al., 2006), the dust scheme of Shaw (2008) with the modifications of Zhang et al. (2012b), and the sea salt scheme of Gong et al. (1997) with an updated treatment for smaller sea-salt particles from O'Dowd et al. (1997), respectively. The initial conditions for meteorological variables and some chemical species such as $\mathrm{CH}_{4}, \mathrm{~N}_{2} \mathrm{O}$, and $\mathrm{O}_{3}$ in all simulations are generated from CCSM3 SRESA1B data set. Initial conditions for additional species not available from CCSM3 outputs (e.g., PAN, $\mathrm{H}_{2} \mathrm{O}_{2}$, and $\mathrm{SO}_{2}$ ) are generated from the Goddard Earth Observing System Model with Chemistry v7-04-12Run0 (GEOS-Chem). The initial conditions obtained from CCSM3 are decadal mean values to reduce interannual variability in the simulations. Thus, the 2050 simulation is initiated by the average of CCSM3 output for the period of 20452054. 2001 was initialized by the average of CCSM3 output from only the 5-year period 2000-2004 due to lack of data during 1995-1999. The initialization of species from GEOSChem data were based on monthly mean values. Since future GEOS-Chem simulations were not available, all years are initialized using the same data set as that for 2001. A 1month spin-up period is used to bring all chemical species into equilibrium with the new emissions and provide initial conditions for missing species. The meteorological fields are re-initialized every month from CCSM3, and the chemical species are initialized based on the previous month's simulation. The additional set of current year simulations is carried out using the reanalysis data from the National Centers for Environmental Prediction Final Operational Analysis (NCEP-FNL) for the meteorological initial conditions. A more detailed description of model configurations can be found in Zhang et al. (2012b).

\section{Representativeness of 2001 and 2050}

The simulation results in 2001 and 2050 are first compared with the averages of AOC and AOF, respectively, to determine their representativeness as a typical year for currentyear and future-year climatology. This is to illustrate that the changes in meteorology between 2001 and 2050 are representative of the climate change signal with longer runs, and therefore the differences presented in this study are representative of climate change rather than differences in simulated meteorology or internal model variability. The predictions of GU-WRF/Chem are also compared with those from an established climate model, i.e., the NCAR's CCSM3 to demonstrate its skills in simulating current and future climate. Figure 1 compares the average MAM $2 \mathrm{~m}$ temperature (T2), $2 \mathrm{~m}$ water vapor mixing ratio $(\mathrm{Q} 2)$, precipitation rate (PR), and planetary boundary layer height (PBLH) for the GU-WRF/Chem 2001 and AOC NCEP-FNL simulations and CCSM3 initial conditions (2000-2014). Similar plots for 

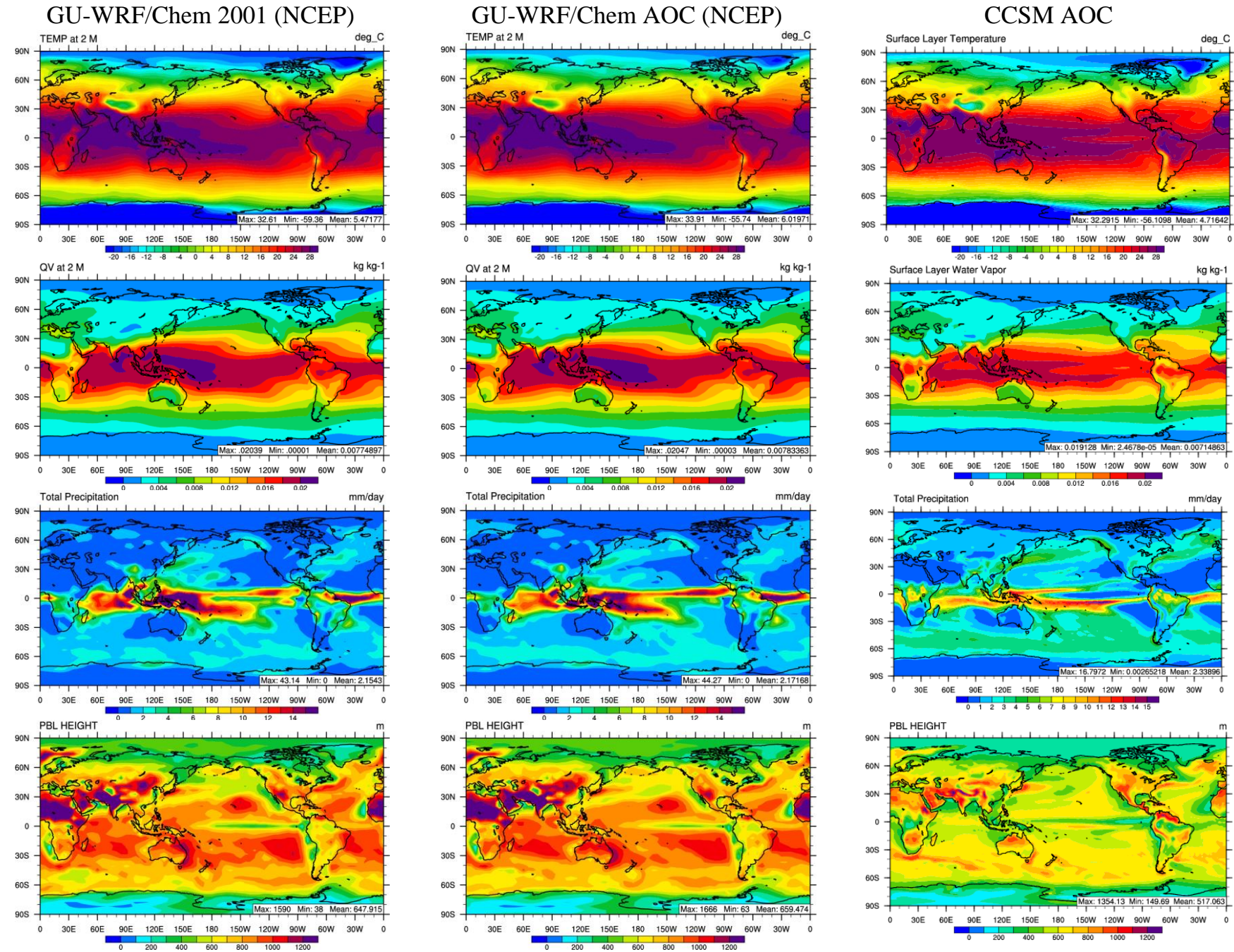

Figure 1. Average spring (MAM) $2 \mathrm{~m}$ temperature, $2 \mathrm{~m}$ water vapor, precipitation rate, and planetary boundary layer height fields from GU-WRF/Chem simulations of the year 2001 (left), averaged current period consisting of 2001 and 2010 (AOC) (center), and the average of the current period 2000-2014 from CCSM3 (right). GU-WRF simulations are initialized with the NCEP-FNL data.

2050 are shown in Fig. 2 in contrast to the AOF from GUWRF/Chem and CCSM3 initial conditions (2015-2055).

In general, the 2001 and 2050 simulations have the same general spatial pattern as the AOC and AOF from GUWRF/Chem, respectively. The global average $\mathrm{T} 2$ in 2001 and 2050 is $\sim-0.6^{\circ} \mathrm{C}$ cooler and $0.5^{\circ} \mathrm{C}$ warmer than the AOC and $\mathrm{AOF}$ values, respectively, while the 2001 mean is $0.75^{\circ} \mathrm{C}$ warmer than the CCSM3 current period and the 2050 mean is $\sim 4.0^{\circ} \mathrm{C}$ warmer than the CCSM3 future period. The discrepancy between GU-WRF/Chem and CCSM3 most likely results from a warm bias of $\sim 1.2{ }^{\circ} \mathrm{C}$ against the National Climatic Data Center (NCDC) global observations for the 2001 MAM period, this level of bias is consistent with other global models (Bader et al., 2004; John and Soden 2007; Tian et al., 2013). The discrepancy between GU-WRF/Chem and CCSM3 predictions in the future period likely results from the GU-WRF/Chem simulation being initialized with CCSM3 data, which appears to generate a warmer atmosphere than the simulation with a shorter re-initialization interval. This is also evident in the current year period initialized with CCSM3 data shown in Supplement Fig. S1. The differences between the individual years of 2001 and 2050 and longer term average AOF and AOC are smaller than the differences between the average current and future periods from both simulations initialized with CCSM 3 data $\left(1.37^{\circ} \mathrm{C}\right.$ warming between 2050 and $2001,0.79^{\circ} \mathrm{C}$ warming between $\mathrm{AOF}$ and $\mathrm{AOC}$, and $1.46^{\circ} \mathrm{C}$ warming between CCSM3 AOF and CCSM3 AOC), indicating that the differences in $\mathrm{T} 2$ between the subset period, i.e., 2050 and 2001, are representative of the average climate change between future and current years. The global average Q2 is $0.08 \mathrm{~g} \mathrm{~kg}^{-1}$ less in 2001 than AOC and $0.02 \mathrm{~g} \mathrm{~kg}^{-1}$ more in 2050 than AOF. 

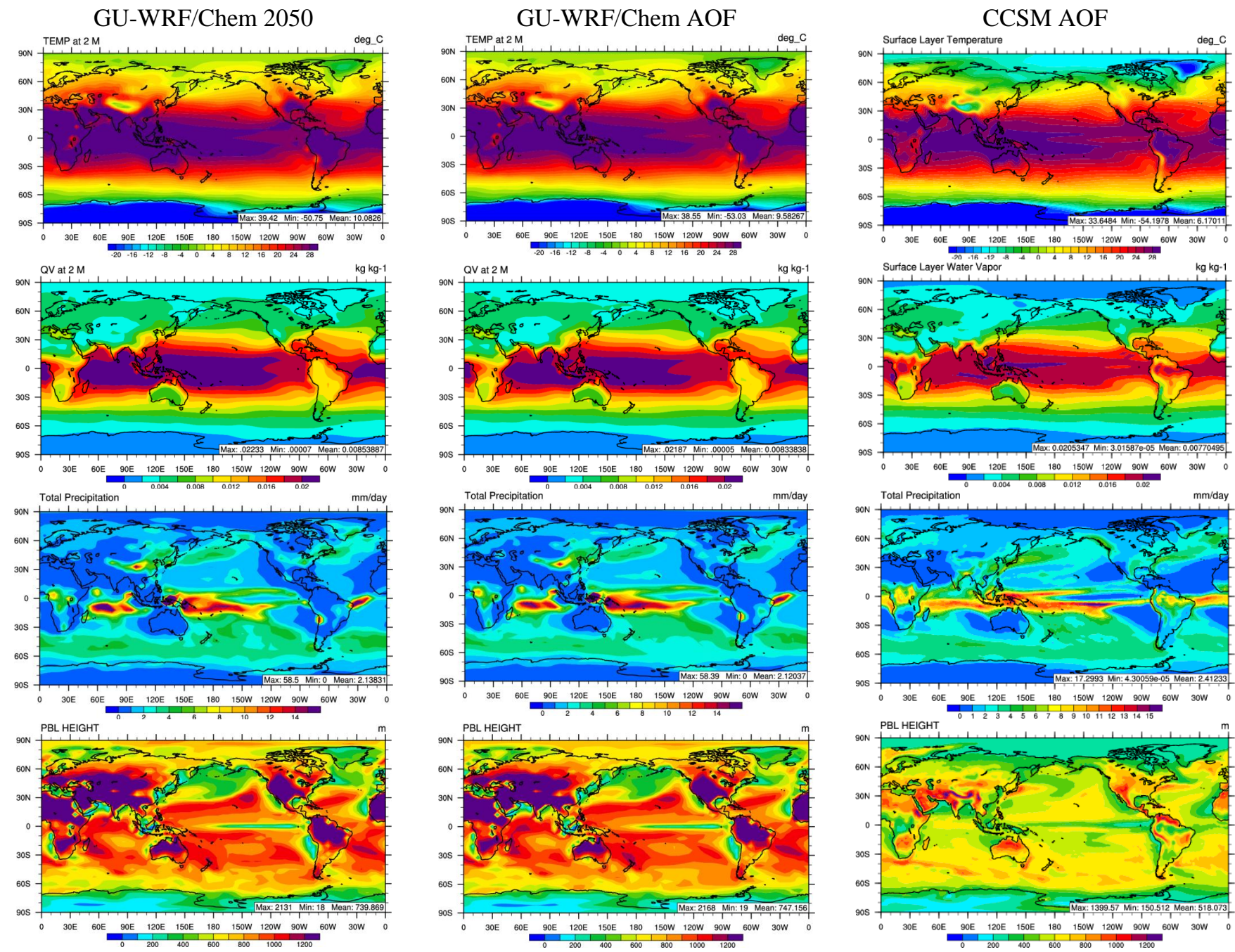

Figure 2. Average spring (MAM) $2 \mathrm{~m}$ temperature, $2 \mathrm{~m}$ water vapor, precipitation rate, and planetary boundary layer height fields from GU-WRF/Chem simulations of the year 2050 (left), averaged future period consisting of 2020, 2030, 2040, and 2050 (AOF) (center), and the average of the future period 2015-2054 from CCSM3 initial conditions (right).

The differences against CCSM3 are higher $\left(0.25 \mathrm{~g} \mathrm{~kg}^{-1}\right.$ between 2001 and CCSM AOC and $0.84 \mathrm{~g} \mathrm{~kg}^{-1}$ between 2050 and CCSM AOF), which may be due to an overprediction of $\sim 0.4 \mathrm{~g} \mathrm{~kg}^{-1}$ in the GU-WRF/Chem baseline simulation. Similarly to T2, the climate change signal between the current and future simulations initialized with CCSM3 data (i.e., $0.67 \mathrm{~g} \mathrm{~kg}^{-1}$ increase between 2050 and 2001, $0.37 \mathrm{~g} \mathrm{~kg}^{-1}$ increase between AOF and AOC, and a $0.55 \mathrm{~g} \mathrm{~kg}^{-1}$ increase between CCSM3 AOF and CCSM3 AOC) is larger than the discrepancies between the single years and the longer term average AOF and AOC of GU-WRF/Chem simulations.

GU-WRF/Chem does not produce a strong climate signal for PR with only small increases of $0.02 \mathrm{~mm} \mathrm{day}^{-1}$ between 2001 and 2050 and $0.01 \mathrm{~mm}$ day $^{-1}$ between AOF and AOC. For comparison, the increase in PR between CCSM3 AOF and CCSM3 AOC is $0.08 \mathrm{~mm} \mathrm{day}^{-1}$. The differences in climate change signal in PR between the two models are mainly due to differences in the cumulus and resolved cloud schemes. These differences are similar in magnitude to the discrepancies between 2001 and AOC $\left(0.01 \mathrm{~mm} \mathrm{day}^{-1}\right)$ and 2050 and $\mathrm{AOF}\left(0.02 \mathrm{~mm} \mathrm{day}^{-1}\right)$, indicating that differences in this parameter cannot clearly be differentiated from internal model variability. Changes in the PBLH between the CCSM3 output and GU-WRF/Chem are quite large. There is a trend of decreasing PBLH in GU-WRF/Chem with global average decreases of $29 \mathrm{~m}$ between 2001 and 2050 and $15 \mathrm{~m}$ between AOF and AOC, whereas the changes in PBLH are insignificant between CCSM3 AOF and AOC (with an increase of $1 \mathrm{~m}$ ). This discrepancy in climate change signal in PBLH between models is due to differences in the PBL parameterizations used in different models (Murazaki and Hess, 2006). However, the climate change signal is much 
larger than the variability between years ( $11 \mathrm{~m}$ between 2001 and AOC and $8 \mathrm{~m}$ between 2050 and AOF).

In order to further illustrate that the differences between the years 2001 and 2050 are indicative of climate change, a number of meteorological variables including T2, Q2, PR, sea level pressure (SLP), the wind speed at $10 \mathrm{~m}$ (WSP10), the wind speed at $5500 \mathrm{~m}$ (WSP5500), net incoming shortwave radiation at the earth's surface (GSW), downwelling long-wave radiation at the earth's surface (GLW), and outgoing long-wave radiation at the top of the atmosphere (OLR) are evaluated against statistical criteria to determine if the differences between these individual years are statistically significant and if the differences are outside the range of current and future climate variability. Statistical significance is determined using a two-tailed student's $t$ test. The distributions of 2001 and 2050 are based on the hourly output from the MAM time period resulting in distributions of 2208 values with the exception of precipitation, which is evaluated daily with 92 values for each distribution. The differences in the mean MAM values are considered to be statistically significant if the probability that the values in each grid cell are from the same distribution is less than $5 \%$ (i.e., $95 \%$ confidence). We quantify interannual variability for a given variable using the standard deviation of the mean MAM values from a 13-year current year period (2000-2013) and a 10-year future year period (2045-2054). In this study we determine that the difference is outside the range in current and future climate variability if the difference between the 2001 and 2050 MAM mean value is greater than one standard deviation of the mean MAM values from both the current and future periods. The current year standard deviation for each variable is computed from both the CCSM3 output and available satellite and reanalysis data sets. These data sets include the National Centers for Environmental Prediction Final Operational Analysis (NCEP-FNL) used to compute the standard deviation in the current MAM means of T2, Q2, WSP10, WSP5500, and SLP, the Global Precipitation Climatology Project (GPCP) used for PR, and the Clouds and Earth's Radiant Energy System Data (CERES) used for GSW, GLW, and OLR. The standard deviation for the future period is also calculated from the CCSM3 output. GLW is not evaluated against CCSM3 data as it is not readily available.

Figure 3 shows the mean MAM difference between 2050 and 2001 that is statistically significant and greater than current and future climate variability for T2, Q2, WSP10, WSP5500, SLP, PR, GSW, GLW, and OLR. T2, Q2, and GLW pass the climate signal test mentioned above on a global scale with global increases of $\sim 1.2^{\circ} \mathrm{C}, \sim 0.82 \mathrm{~g} \mathrm{~kg}^{-1}$, and $\sim 8.0 \mathrm{Wm}^{-2}$, respectively. The differences in WSP5500, SLP, and OLR tend to be significant on a more regional basis. The regional changes in SLP near Alaska and changes in WSP5500 over East Asia and western North America have important consequences on intercontinental transport and are discussed in greater detail in Sect. 5. Although the significant changes in OLR are regional in nature, there is a decrease on global average of $\sim 1.2 \mathrm{Wm}^{-2}$. This decline in OLR and increase in GLW is consistent with enhanced anthropogenic long-wave radiative forcing from increases in greenhouse gases. Compared to the other variables, the significant differences in PR, WSP10, and GSW have much less spatial coverage, indicating that these variables have a much weaker climate change signal. This is also consistent with the above analysis of the differences in the PR means. However, some of the significant differences in WSP10 are important to changing transport patterns discussed in Sect. 5. The significant differences in GSW show a global decrease of $\sim 2.1 \mathrm{Wm}^{-2}$, consistent with the cloudier and more aerosol-rich atmosphere that is predicted in the future by GU-WRF/Chem. Similar analysis is performed on the difference between the MAM AOF and AOC time periods as shown in the Supplement Fig. S2. Supplement Fig. S2 shows similar changes to Fig. 3 in general with slightly less of a robust signal. This is a result of the fact that the AOF and AOC time periods are the averages of multiple years spaced 10 years apart, and thus the trend between 2050 and 2001 is dampened during the averaging, resulting in more of the values falling into the range of interannual variability or being less statistically significant.

Overall, although some differences between climate change signals obtained using single year differences (i.e., 2050-2001) versus multi-year average differences (i.e., averages of 2020, 2030, 2040, and 2050 minus averages of 2001 and 2010) are due to interannual variability, the above comparison suggests that the differences in meteorology and subsequently chemistry between the 2001 and 2050 simulations are generally representative of a climate change signal obtained using multi-year averages of GU-WRF/Chem simulations. The climate change signals from both the subset of years and the GU-WRF/Chem averages for temperature and humidity are comparable to those from CCSM3, demonstrating the skills of GU-WRF/Chem in simulating current and future climate. Some differences exist for PR and PBLH simulated by the two models, mainly because they are more sensitive to the individual models' physical parameterizations (i.e., cumulus/resolved cloud and PBL schemes) than temperature and water vapor. The changes in temperature, humidity, long-wave radiation, wind speeds, and SLP between the individual years have also largely been shown to be statistically significant and greater than one standard deviation of the mean MAM values from both a 13-year current and 10-year future climate period.

\section{Changes in future emissions}

As mentioned in Sect. 2, the future emissions projections for this work are generated using region-wide growth factors for 17 world regions for the A1B emission scenario. Thus, the emissions projection in this case will be referred to as 


\section{Satellite/Reanalysis}
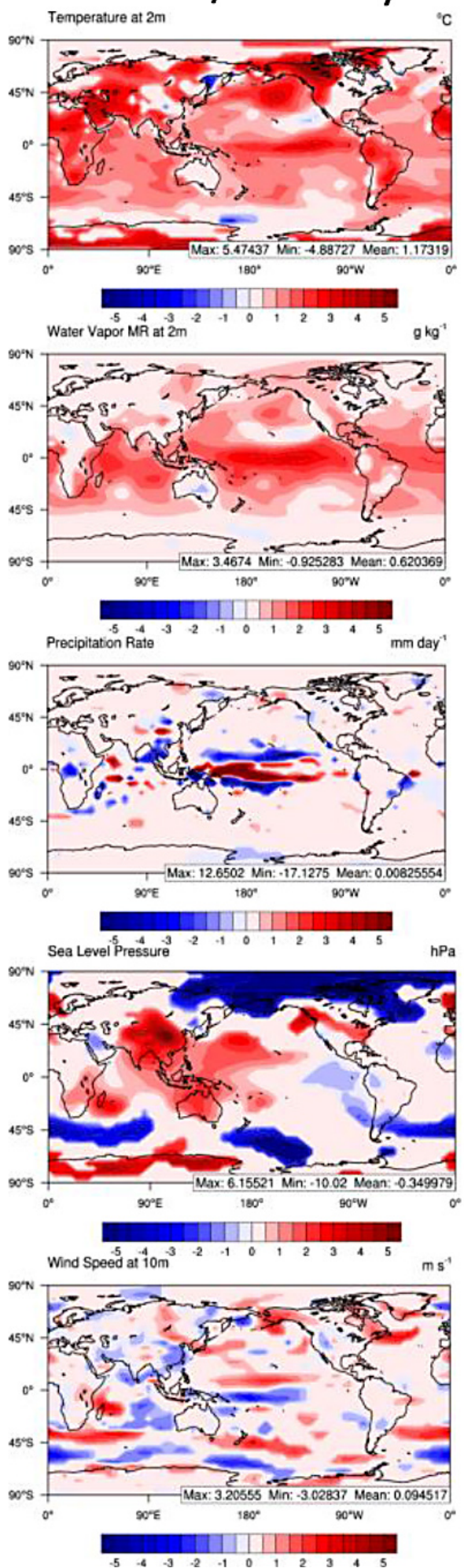

\section{CCSM3}
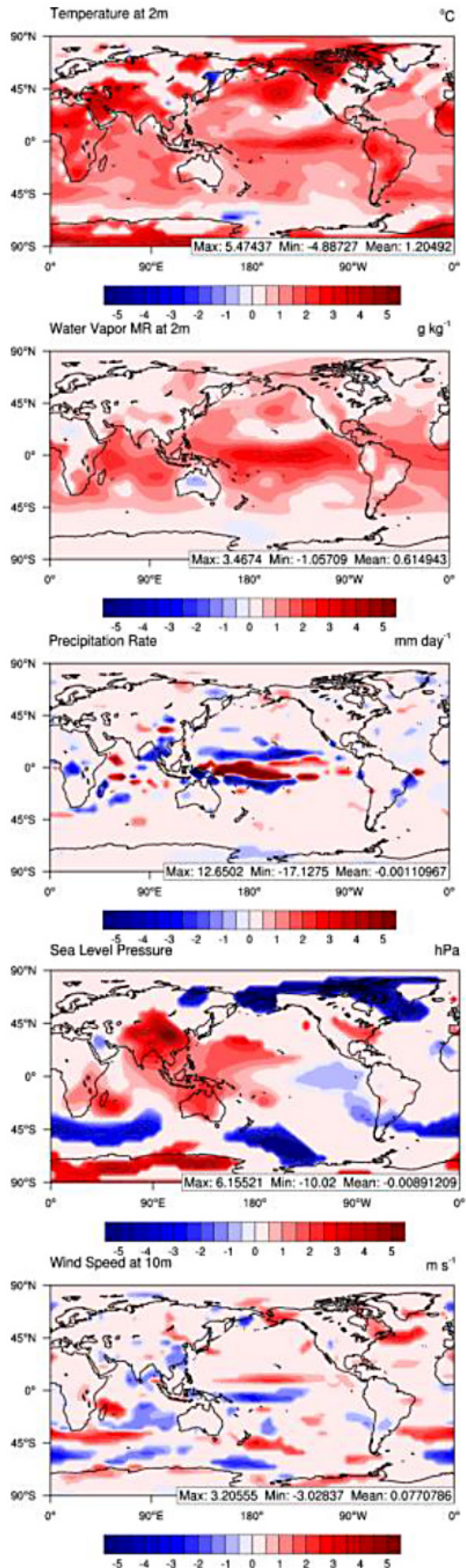

Figure 3a. The statistically significant differences in T2, Q2, SLP, WSP10, WSP5500, PR, GSW, OLR, and GLW between MAM 2050 and 2001 that are greater than the variability in the current climate from reanalysis or satellite data (left) and greater than the variability in the current and future climate from CCSM3 (right). The GLW plot in the bottom row of the CCSM3 column was not generated since the CCSM3 GLW data were not readily available. 


\section{Satellite/Reanalysis}
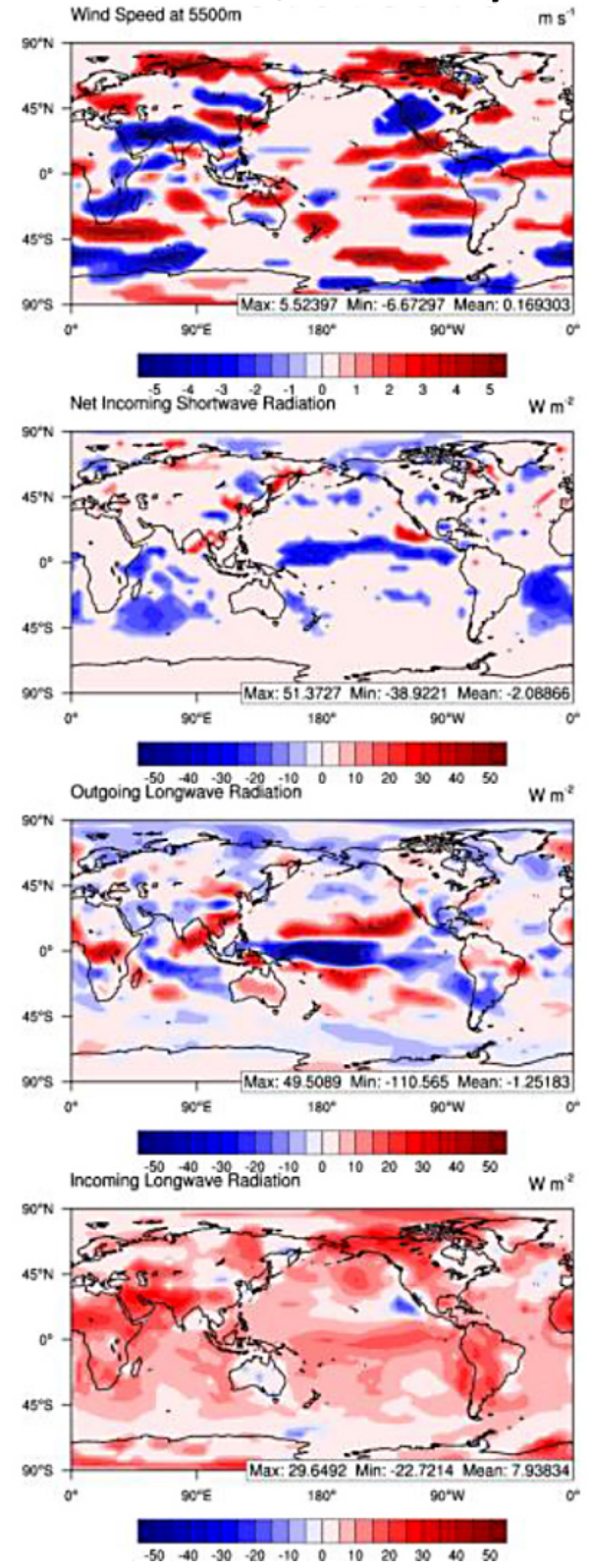

Figure 3b. Continued.

GU-WRF/Chem A1B since the future emissions are derived from the GU-WRF/Chem base emissions inventory. Figure 4 shows the logarithm of the effective growth factors for the 2050 emissions versus the 2001 baseline emissions. The anthropogenic emissions of $\mathrm{O}_{3}$ precursors, $\mathrm{NO}_{\mathrm{x}}$ and VOCs, increase over most of the globe, with the exception of the US, Canada, western Europe, Australia, and portions of northern Asia, leading to global average increases by $38 \%$ and $23 \%$, respectively, according to the $\mathrm{A} 1 \mathrm{~B}$ scenario. The East Asian region $\mathrm{NO}_{\mathrm{x}}$ increases by $\sim 25-300 \%$ and $\mathrm{VOC}$ increases by $\sim 25-150 \%$, indicating a potential for increased $\mathrm{O}_{3}$ and

\section{CCSM3}
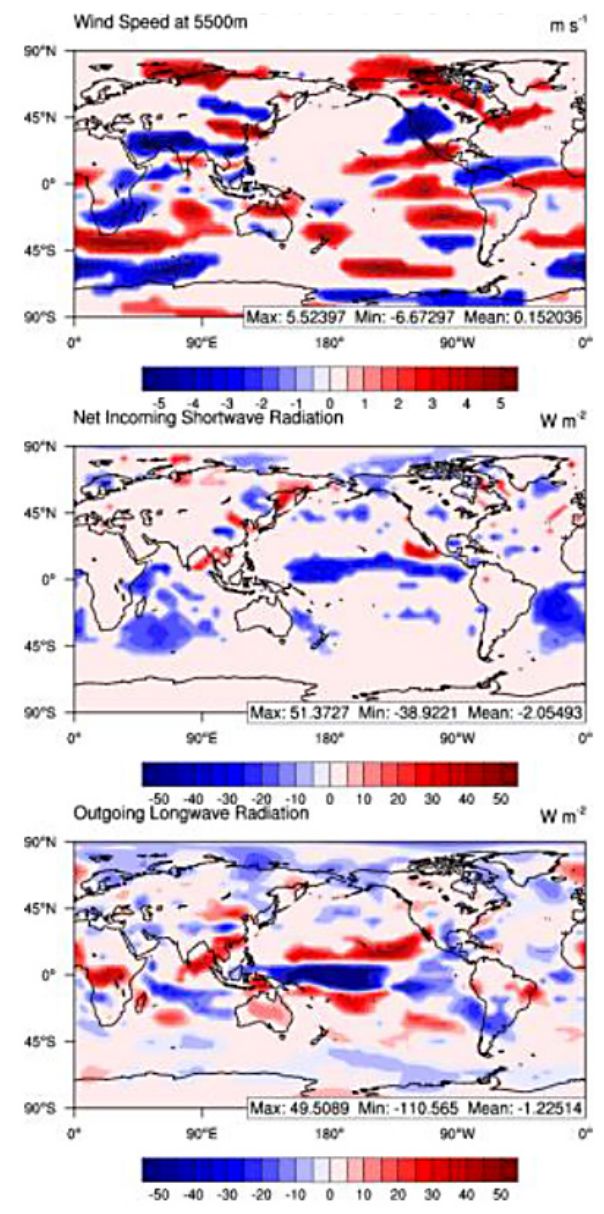

peroxyacetyl nitrate (PAN) production in East Asia. Anthropogenic $\mathrm{CO}$ emissions decrease by $\sim 11 \%$ on global average. Developed regions in North America, Australia, Europe, and northern Asia show the largest declines ( 20-97\%), while developing regions in Africa, South America, and South Asia experience increasing emissions (25-280\%). The impact of these emissions on total East Asian $\mathrm{CO}$ emissions is uncertain, as the decrease over China and increases over South East Asia are similar $(<25 \%)$, and there are increases in biogenic emissions over Southeast Asia and northeastern 

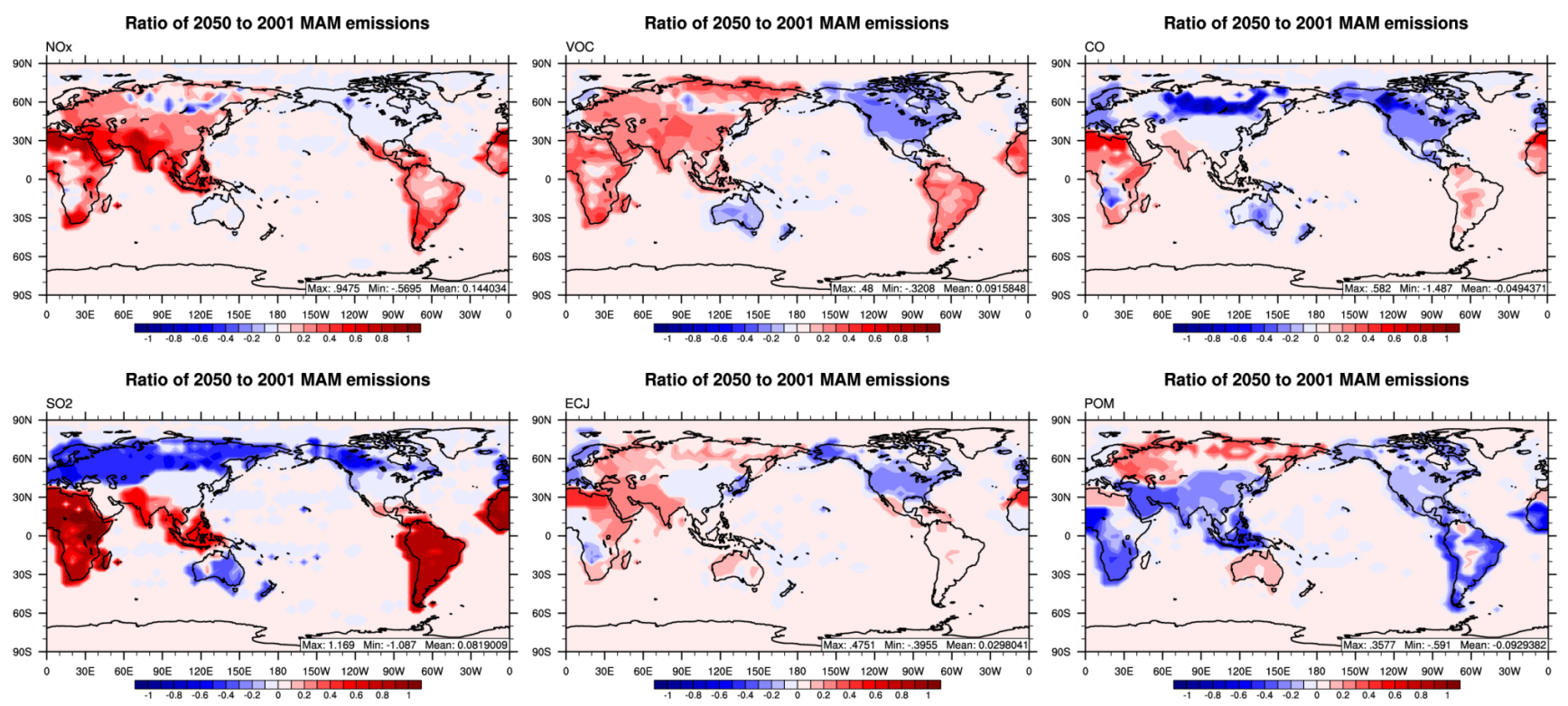

Figure 4. The logarithm of the ratio of 2050 spring (MAM) emissions to the 2001 MAM emissions of $\mathrm{NO}_{\mathrm{x}}$, total non-methane VOC, CO, $\mathrm{SO}_{2}$, black carbon, and primary organic carbon.

China (figure not shown) that may have some impacts $(10$ $30 \%)$.

The trends vary in anthropogenic emissions of fine particulate matter $\left(\mathrm{PM}_{2.5}\right)$ precursors and primary anthropogenic emissions. $\mathrm{SO}_{2}$ emission reductions over the Northern Hemisphere vary from smaller decreases $(<20 \%)$ in China, Japan, and the US to larger decreases (60-92\%) in Europe and northern Asia. These decreases are compensated by large increases (99-1500\%) in South Asia, South America, and Africa, leading to a global average increase by $20 \%$. The trend is slightly different for $\mathrm{NH}_{3}$ emissions (not shown) with decreases by less than $20 \%$ in the conterminous US, 20-37\% in China, and 50-83\% in Europe and increases by $25-99 \%$ in Mexico, northern Asia, and South America and larger increases in Africa of up to $195 \%$. Black carbon (BC) emissions are reduced largely in the US, Canada, Japan, western Africa, and western Europe (20-60\%) with smaller decreases in China $(<20 \%)$ and increases over the remainder of the globe. Emissions of primary organic aerosol (POM) largely decrease by $20-75 \%$ over much of the globe, with the exception of northern Asia, North Africa, Australia, and portions of South America, leading to a global average decrease by $\sim 19 \%$. These emission changes give no clear insight into the possible changes in East Asian $\mathrm{PM}_{2.5}$ as changes over Southeast Asia are typically opposite to those over China and Japan. Overall, North America, with the exception of Mexico, will experience a decline in local anthropogenic emissions by 2050 based on the A1B scenario. Thus, increases in ambient concentrations of pollutants in NA could be attributed to enhanced transport from other regions, enhanced natural emissions, or enhancements from climate change.
The SRES A1B emissions used in this study are not directly comparable to any of the current IPCC representative concentration pathway (RCP) emission scenarios because the two sets of emission scenarios were derived using fundamentally different approaches. The A1B SRES scenario was developed for IPCC AR4 based on detailed socioeconomic storylines to generate emissions. RCP emissions were developed for the IPCC Fifth Assessment Report (AR5) by a parallel process for the identification of important characteristics for scenarios of radiative forcings for climate modeling (Moss et al., 2010). RCP emissions are thus climate policy scenarios that provide inputs for climate and atmospheric chemistry modeling, and they are not designed to span a range of socio-economic conditions. A set of emission scenarios that are based on updated socioeconomic pathways is being developed, i.e., the Shared Socioeconomic Pathways (SSPs) (Kriegler et al., 2012; van Vuuren et al., 2012), which is more comparable to the SRES emission scenarios.

Nevertheless, it is still useful to compare the two sets of emission scenarios because they provide an important outlook on future emissions and have been widely used. The moderate RCP pathway with a stabilization of anthropogenic radiative forcing at $6 \mathrm{Wm}^{-2}$ by 2100 (RCP6) is an updated version of the SRES B2 scenario which predicts less greenhouse gas emissions in the near future compared to A1B (IPCC, 2000; Masui et al., 2011). The RCP scenario with a stabilization of anthropogenic radiative forcing at $8.5 \mathrm{Wm}^{-2}$ by 2100 (RCP8.5) is an updated version of the SRES A2 scenario, which has similar or slightly larger increases in greenhouse gas emissions compared to A1B (IPCC, 2000; Riahi et al., 2011). A comparison of the temporal evolution of global 
and East Asian emissions of NO, VOCs, BC, primary organic carbon (POC), $\mathrm{CO}, \mathrm{SO}_{2}$, and $\mathrm{NH}_{3}$ for the GU-WRF/Chem A1B, RCP6, and RCP8.5 emissions scenarios is shown in Figs. S3 and S4 in the Supplement.

Globally all species, except $\mathrm{CO}$ and NO, have emissions that are larger than the RCP scenarios for the base year (2001 for GU-WRF/Chem A1B and 2000 for RCP). The largest differences between the emission inventories occur for VOCs, $\mathrm{BC}$, and POC, where the emissions used in GU-WRF/Chem A1B are roughly 1 to 2 orders of magnitude larger than those from the RCP scenarios. Assuming the same atmospheric conditions, this implies that the predictions of anthropogenic $\mathrm{PM}_{2.5}$ and $\mathrm{O}_{3}$ from GU-WRF/Chem will generally be larger than those predicted using the RCP scenarios. The global trend in VOC emissions between all scenarios is roughly the same, where emissions increase and then decline to 2050. In the GU-WRF/Chem A1B scenario, the emissions of BC and POC decrease from 2001 to 2030 and then increase from 2030 to 2050 . This is an opposing trend to the RCP scenarios, where BC and POC decline from 2000 to 2050. In the case of CO, the GU-WRF/Chem A1B scenario shows increasing emissions until 2030 followed by decreases in emissions to 2050 in contrast to the general decreasing trend in both RCP scenarios. $\mathrm{NO}$ and $\mathrm{SO}_{2}$ emissions from the GU-WRF/Chem A1B scenario increase from the base year through 2050, while both RCP scenarios generally predict decreasing emissions. There is an opposing trend in $\mathrm{NH}_{3}$ emissions as GU-WRF/Chem A1B predicts a slight increase by 2030 and then a much sharper decline to 2050 compared to the general increasing trend in $\mathrm{NH}_{3}$ emissions from the RCP emission scenarios. Overall, these trends would suggest that the GU-WRF/Chem A1B scenario will predict a more polluted future compared to what would be predicted using the RCP scenarios.

The East Asia trends shown in Supplement Fig. S4 differ from the general global trends discussed above in Supplement Fig. S3. The trends in the emissions of NO, VOC, and $\mathrm{SO}_{2}$ in East Asia from GU-WRF/Chem A1B scenario are more comparable to the RCP6 scenario than RCP8.5, while the trends in $\mathrm{BC}, \mathrm{POC}$, and $\mathrm{CO}$ are more comparable to the RCP8.5 scenario. Also, the GU-WRF/Chem A1B trend in $\mathrm{NH}_{3}$ emissions is strikingly different from the RCP scenarios. During the time period considered here, this implies that anthropogenic production of $\mathrm{O}_{3}$ in East Asia would be the largest in 2050 following the GU-WRF/Chem A1B and RCP6 scenarios with greater production in the GUWRF/Chem A1B scenario, while in the RCP8.5 scenario $\mathrm{O}_{3}$ production would be at its greatest in the year 2020 . This of course assumes that changes in emissions will dominate over changes in meteorology. The East Asian trend in primary aerosols from the GU-WRF/Chem A1B scenario is more comparable to the RCP8.5 scenario, as both scenarios experience decreasing emissions by 2050 , unlike the RCP6 scenario that predicts increasing primary aerosol emissions. However, because the primary emissions from GU-
WRF/Chem are much larger than the RCP emissions, it will always predict greater concentrations than either RCP scenario. The differences in emissions also imply differing possible changes in secondary aerosol formation. In the GUWRF/Chem A1B scenario and the RCP6 scenario, the sulfate formation in East Asia is expected to be enhanced around 2050 due to increasing $\mathrm{SO}_{2}$ emissions with a greater enhancement in GU-WRF/Chem A1B, while the sulfate formation for RCP8.5 should be reduced in 2050 due to declining $\mathrm{SO}_{2}$ emissions. The increasing $\mathrm{NH}_{3}$ emissions in both RCP scenarios also allow for the possibility of increased secondary aerosol formation even with decreasing $\mathrm{SO}_{2}$ emissions, since the increased availability of $\mathrm{NH}_{3}$ may help enhance nitrate formation given suitable atmospheric conditions. Similarly, the decline in $\mathrm{NH}_{3}$ emissions in GUWRF/Chem A1B may limit the impact of increased $\mathrm{SO}_{2}$ emissions and could potentially reduce nitrate formation, given suitable conditions.

\section{Impact of EAAEs on current and future air quality}

The predicted flow patterns at $10 \mathrm{~m}$ and $5500 \mathrm{~m}$ and the sea level pressure for 2001, 2050, AOC, and AOF are shown in Fig. 5, which illustrates two major pathways of ITAP for East Asia. At the surface, there is both a southerly track that exports pollutants to the Arctic due to the cyclonic circulation around the Aleutian Low and a westerly track that transports pollution to western North America from anticyclonic circulation around the Pacific High. This is similar to the findings reported in Zhang et al. (2008), which indicated that these two transport pathways were considered to be representative of trans-Pacific transport climatology. In general, the surface pressure patterns are similar among all scenarios with a few key exceptions. In 2050, 2050_CCO (figure not shown), and AOF the Aleutian Low strengthens leading to greater circulation than in 2001 or AOC, which results in enhanced transport to the Arctic. Additionally, there is an increase in sea level pressure off the coast of Scandinavia (to a lesser extent in AOF than 2050) which increases the wind speeds over northern Europe and Scandinavia compared to 2001 and AOC. In the free troposphere, transport is primarily westerly. Simulated wind speeds aloft increase over polluted portions of East Asia and decrease over western North America in 2050, 2050_CCO, and AOF. This increases the westerly export of pollutants lofted into the free troposphere from East Asia, while simultaneously increasing the lifetime of these pollutants over North America, and thus increases the likelihood of subsidence to the surface in the receptor regions.

Figure 6 shows the differences in maximum $8 \mathrm{~h} \mathrm{O}_{3}$ mixing ratio and the differences in the 24 to $60^{\circ} \mathrm{N}$ meridional averaged vertical profiles of $\mathrm{O}_{3}$ between the simulations with and without EAAEs for 2001, 2050, and 2050_CCO. In 2001, O 3 generated by EAAEs contributes $1.2 \mathrm{ppb}$ to the maximum 
2001

$10-\mathrm{m}$
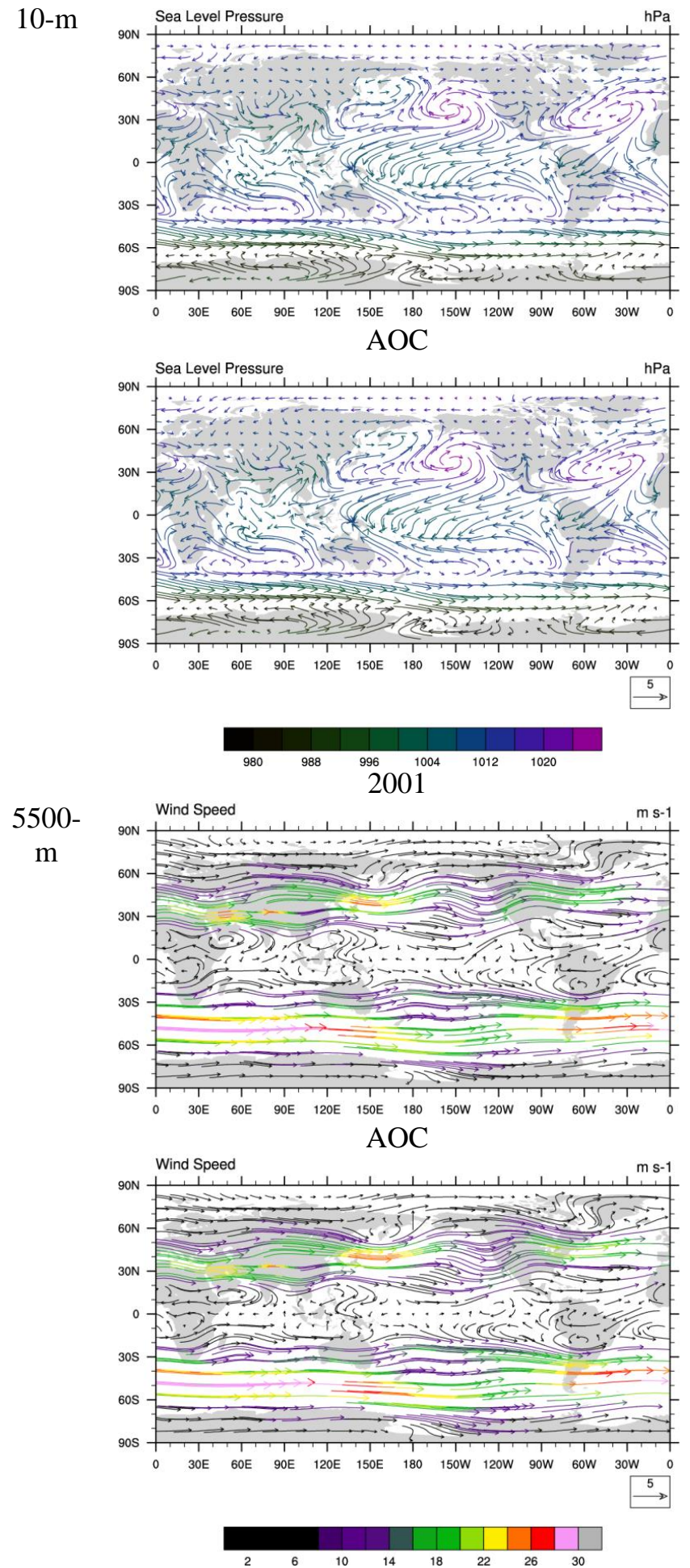

2050
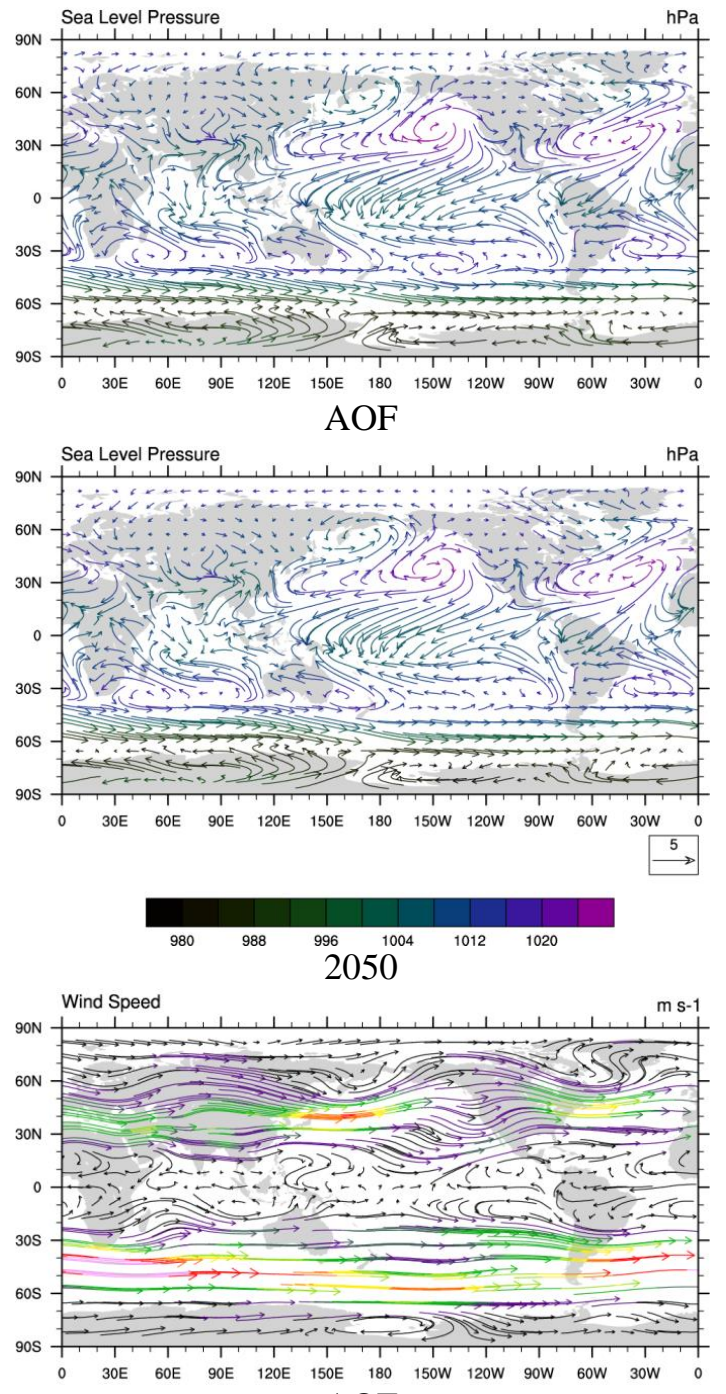

$\mathrm{AOF}$

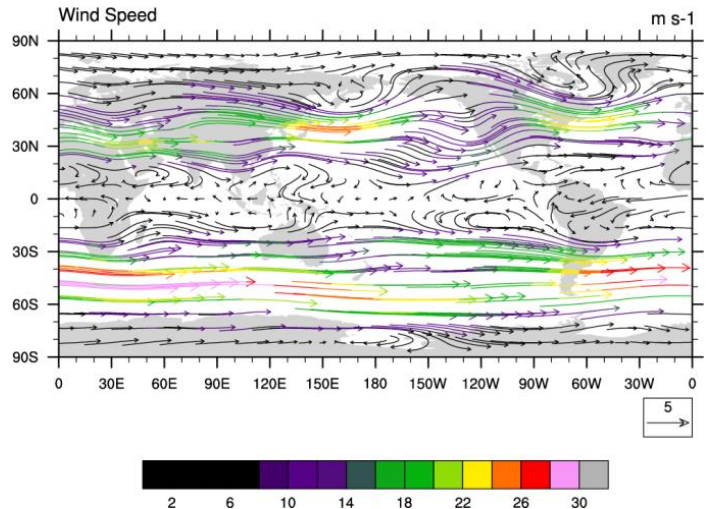

Figure 5. The average spring (MAM) weather patterns at the surface (top) and $5500 \mathrm{~m}$ (bottom) for 2001 and the average current period (left), 2050 and the average future period (right) from the baseline simulations. The surface plots depict the wind vectors from the $10 \mathrm{~m}$ wind components and the color scale is based on the sea level pressure. The $5500 \mathrm{~m}$ vectors are derived from the wind components interpolated to that height and the color scale is the magnitude of the wind speed. 
2001
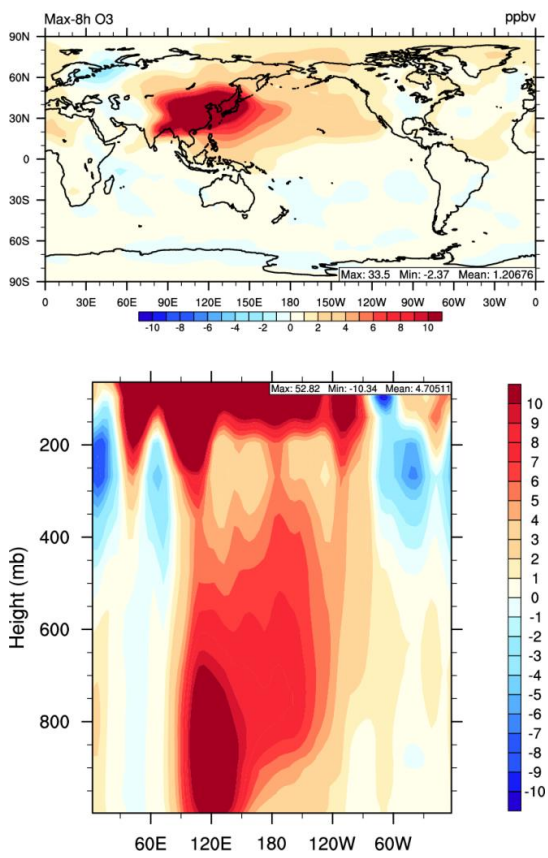

2050
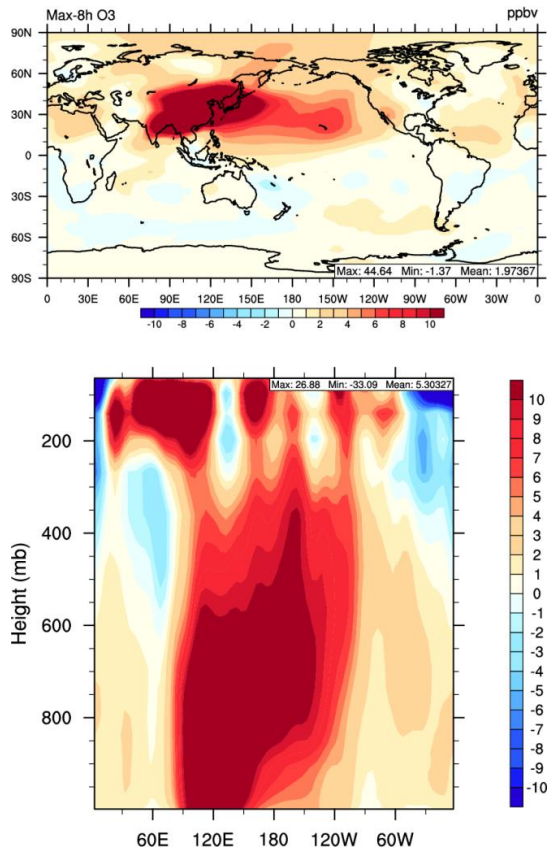

2050_CCO
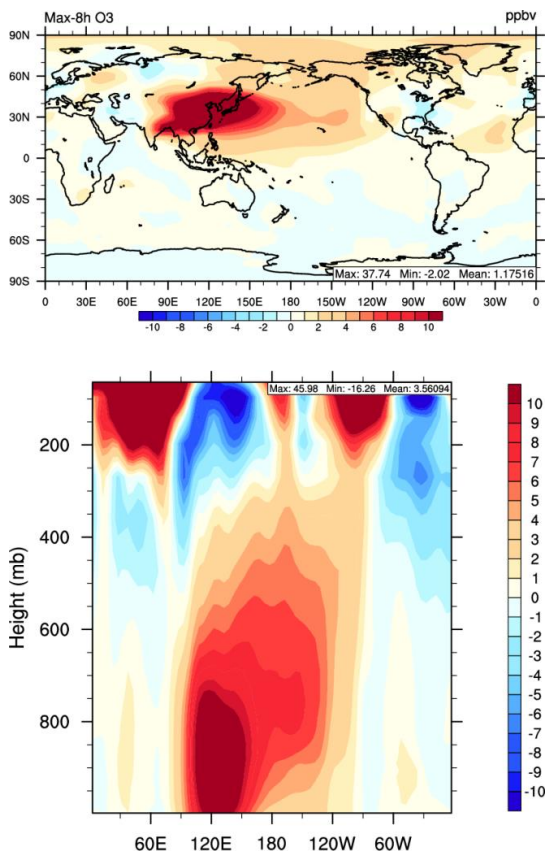

Figure 6. The difference in the spring (MAM) maximum $8 \mathrm{~h}$ average surface ozone mixing ratio (top) and the mid-latitude $\left(24^{\circ} \mathrm{N}\right.$ to $\left.60^{\circ} \mathrm{N}\right)$ meridional averaged vertical cross section of ozone (bottom) between the simulations with and without EAAEs for the current (2001) and future (2050 and 2050_CCO) scenarios.

$8 \mathrm{~h} \mathrm{O}_{3}$ on a global average, with higher values in several regions (e.g., 3-33.5 ppb in East Asia, 1-2 ppb in western North America, and 1-3 ppb in the Arctic). In 2050, this contribution increases to $\sim 2 \mathrm{ppb}$ of maximum $8 \mathrm{~h} \mathrm{O}_{3}$ on a global average, and in several regions (e.g., 4-44.6 ppb in East Asia and $2-5 \mathrm{ppb}$ in western North America and the Arctic). This is primarily a result of projected increases in East Asian emissions of $\mathrm{O}_{3}$ precursors in the future, with some regional enhancement from climate change. The 2050_CCO simulations have the same contribution of $1.2 \mathrm{ppb}$ on global average as 2001, but a somewhat different pattern in regional contributions (e.g., 3-37.7 ppb in East Asia, 1-3 ppb in western North America and the Arctic). The differences in $\mathrm{O}_{3}$ between the 2001 and 2050_CCO simulations are the result of the $1-3^{\circ} \mathrm{C}$ increase in temperature over most of East Asia (except southeast China with cooling by $\sim 1^{\circ} \mathrm{C}$ ) and changes in the atmospheric flow pattern. 2050 has enhanced Arctic transport from the enhanced circulation around the Aleutian Low, which leads to an increase of $\mathrm{O}_{3}$ in the Arctic, especially Alaska and western Canada. The 2050_CCO simulations show eastward and northward transport of the plume that is stronger than 2001 due to higher temperatures but weaker than 2050 due to lower $\mathrm{O}_{3}$ precursor emissions. There is also an enhancement in western Mexico, due to a combination of less water vapor, which increases the lifetime of $\mathrm{O}_{3}$, and greater subsidence of $\mathrm{O}_{3}$ from the reduction in wind speeds aloft.
The vertical cross sections of $\mathrm{O}_{3}$ show large differences between 850 and $400 \mathrm{mb}$ for all simulations and the gradients are tilted toward the east, indicating that the $\mathrm{O}_{3}$ is uplifted and carried eastward. A strong gradient exists near the surface from $120^{\circ} \mathrm{E}$ to $120^{\circ} \mathrm{W}$, indicating a significant transport of $\mathrm{O}_{3}$ in the PBL between East Asia and western North America. In 2050, greater generation of $\mathrm{O}_{3}$ from increased precursor emissions and temperatures leads to greater lofting of $\mathrm{O}_{3}$ into the $\mathrm{FT}$ and subsequently greater subsidence of $\mathrm{O}_{3}$ downwind compared to 2001. In 2050_CCO, there is less lofting and thus less of a downwind impact on $\mathrm{O}_{3}$ as compared to 2001. This results from increases in atmospheric stability, particularly from the surface to $\sim 850 \mathrm{mb}$, which inhibits vertical transport. This indicates that future emission changes may overwhelm natural transport restrictions from climate change.

EAAEs also enhance the levels of other trace gases such as carbon monoxide $(\mathrm{CO})$, sulfur dioxide $\left(\mathrm{SO}_{2}\right)$, and peroxyacetyl nitrate (PAN). EAAEs contribute $\sim 13 \mathrm{ppb}$ and $\sim 16 \mathrm{ppb}$ to the global average $\mathrm{CO}$ level under the current and future scenarios, respectively; the increase in 2050 mainly results from emission increases in Southeast Asia as the 2050_CCO simulations with and without EAAEs show only a slightly increased contribution $(\sim 14 \mathrm{ppb}$ on global average) as compared to 2001. The impact of EAAEs is fairly uniform across the entire $\mathrm{NH}$ where they typically account for 5-10 and 10-30 ppb of the CO level in 2001 and 2050, 
respectively, but the impact is greater in immediate downwind regions such as North America, where the impact is 10$25 \mathrm{ppb}$ in 2001 and $15-35 \mathrm{ppb}$ in 2050. EAAE-induced $\mathrm{SO}_{2}$ has a weak transport signal as it accounts only for $\sim 1-5 \mathrm{ppb}$ in local areas of eastern China and northeast India under current and future scenarios, but has a negligible contribution elsewhere. EAAEs contribute $\sim 2 \mathrm{ppb} \mathrm{SO}_{2}$ to the 24 to $60^{\circ} \mathrm{N}$ meridional averaged surface concentrations with a decreased contribution of $\sim 0.05 \mathrm{ppb}$ up to $\sim 450 \mathrm{mb}$ between $75^{\circ} \mathrm{E}$ and $150^{\circ} \mathrm{E}$ and negligible contributions elsewhere. PAN exhibits a similar spatial distribution of contributions as $\mathrm{O}_{3}$ since they share the same precursors. In 2001, EAAEs contributed $\sim 0.04 \mathrm{ppb}(0.2-1.0 \mathrm{ppb}$ East Asia) to the global average PAN level and this nearly doubles to $\sim 0.07 \mathrm{ppb}(0.2$ $1.8 \mathrm{ppb}$ in East Asia) in 2050 as a result of increased precursor emissions. The 2050 emission increase also generates contributions of $0.1-0.2 \mathrm{ppb}$ to the PAN level over the majority of the $\mathrm{NH}$ compared to a more negligible contribution in 2001. The $24^{\circ} \mathrm{N}$ to $60^{\circ} \mathrm{N}$ meridional averaged vertical PAN contribution exhibits a similar trend. In 2001 EAAEs contribute $\sim 0.3-0.5 \mathrm{ppb}$ of PAN in East Asia between the surface and $700 \mathrm{mb}$. The contribution is $\sim 0.1-0.2 \mathrm{ppb}$ over much of the North Pacific and portions of western North America above $900 \mathrm{mb}$, indicating that there is transport aloft but the subsidence to the surface is negligible. In 2050, the contribution over East Asia increases to $\sim 0.3-0.9 \mathrm{ppb}$ from the surface to roughly $450 \mathrm{mb}$ due to the increase in precursor emissions. The enhancement of PAN aloft leads to additional eastward transport with contributions of $\sim 0.1-0.2 \mathrm{ppb}$ at the surface in western North America, Europe, and North Africa due to subsidence.

Figure 7 shows the differences in the $24 \mathrm{~h}$ averaged surface concentrations and the 24 to $60^{\circ} \mathrm{N}$ meridional averaged vertical profiles of $\mathrm{PM}_{2.5}$ with and without EAAEs for 2001, 2050, and 2050_CCO. The impact of EAAEs on $\mathrm{PM}_{2.5}$ is not as homogeneous as the impact on some trace gases because its concentration and formation are more sensitive to changes in climate. On a global average, EAAEs account for $0.3-0.4 \mu \mathrm{g} \mathrm{m}^{-3}$ in all scenarios with a slight increase from 0.32 in 2001 to $0.39 \mathrm{\mu g} \mathrm{m}^{-3}$ in 2050 on a global average but larger increases in some regions (e.g., up to $3 \mu \mathrm{g} \mathrm{m}^{-3}$ in the Pacific Ocean) (despite projected reductions in primary aerosol emissions in 2050), with most of the positive contributions over East Asia and the North Pacific. Over the interior of North America in all scenarios, EAAEs reduce the surface $\mathrm{PM}_{2.5}$ level by $0.5-1.5 \mu \mathrm{g} \mathrm{m}^{-3}$. This can be attributed to the increased PBLH generated by EAAEs in this region. The mechanism by which EAAEs can impact PBLH is discussed in greater detail in Sect. 6. A similar situation occurs over Scandinavia in the 2001 simulations, where EAAEs reduce the local $\mathrm{PM}_{2.5}$ level (by $\sim 0.5-3 \mu \mathrm{g} \mathrm{m}^{-3}$ ). This impact is larger than that over North America due to low wind speed conditions over Scandinavia, during which vertical mixing becomes the strongest meteorological process impacting $\mathrm{PM}_{2.5}$ (with wind speeds $<1 \mathrm{~m} \mathrm{~s}^{-1}$ ), but does not oc- cur in 2050 or 2050_CCO due to the low pressure center that moves into this area in the future scenarios. Feedbacks from EAAEs to the $10 \mathrm{~m}$ wind speed (see Fig. 9) are distinctly different among all scenarios, which lead to differences in the concentrations of sea salt emitted in marine environments and concentrations of dust emitted over North Africa. This implies that such feedbacks are heavily dependent on both anthropogenic emissions and climate. The contribution to the vertical distribution of $\mathrm{PM}_{2.5}$ shows distinct difference between the impact in the PBL and lower FT, where the impact can be either an increase or a decrease, and that in the middle and upper free troposphere, where the impact is entirely an increase. This occurs because only stratiform cloud feedbacks are treated in this version of the model, and these clouds are typically not present above $\sim 500 \mathrm{mb}$. At this altitude, EAAEs increase the $\mathrm{PM}_{2.5}$ level by $0.1-1.0 \mu \mathrm{g} \mathrm{m}^{-3}$. This is why the impact on aerosol optical depth (AOD) (see Sect. 6) is almost entirely an increase over most of the $\mathrm{NH}$ despite the surface $\mathrm{PM}_{2.5}$ impact being either positive or negative.

Figure 8 shows the contributions of EAAEs to surface BSOA and the total deposition fluxes of total nitrogen, black carbon, and mercury (TNTD, BCTD, and HgTD, respectively) (i.e., the differences in the surface BSOA, TNTD, BCTD, and HgTD between the simulations with and without EAAEs for 2001 and 2050). EAAEs demonstrate a strong impact on the BSOA in East Asia. EAAEs increase BSOA in East Asia by $0.1-1.2 \mu \mathrm{g} \mathrm{m}^{-3}(10-81 \%)$ with large areas experiencing an increase of $0.5-1.2 \mu \mathrm{g} \mathrm{m}^{-3}(50-81 \%)$ under all scenarios, indicating that a large fraction of BSOA in East Asia is controllable through controlling EAAEs that affect the oxidant levels for the oxidation of BSOA precursors. These results are consistent with the work of Carlton et al. (2010), who reported that over $50 \%$ of the BSOA is controllable over the southeastern US by reducing the anthropogenic emissions that increase atmospheric oxidant levels. However, further downwind EAAEs can decrease the amount of BSOA as they reduce incoming shortwave radiation fluxes at the earth's surface (ISR), in turn decreasing the photolytic rate of $\mathrm{NO}_{2},\left(\mathrm{JNO}_{2}\right)$, and the amount of hydroxyl radical available to oxidize BSOA precursors.

EAAEs account for $\sim 0.01-0.9 \mathrm{~g} \mathrm{~m}^{-2}$ month $^{-1}(40-98 \%)$ of TNTD in East Asia and the North Pacific in 2001 and $\sim 0.01-0.6 \mathrm{~g} \mathrm{~m}^{-2}$ month $^{-1}(20-97 \%)$ in 2050. The decrease in 2050 is the result of a projected decrease in emissions of $\mathrm{NH}_{3}$. This indicates that EAAEs are a contributor to the nitrogen fertilization of the Pacific Ocean and can enhance ocean productivity in areas that are nitrogen limited (Duce et al., 2008). Another key difference in 2050 is an increase of 0.001-0.002 $\mathrm{g} \mathrm{m}^{-2}$ month $^{-1}(10-40 \%)$ in TNTD over Alaska and other portions of the Arctic due to enhanced southerly transport as compared to 2001. This enhanced Arctic deposition may help fertilize Arctic vegetation increasing their growth (Schindler and Bayley, 1993), thus potentially amplifying the climate feedbacks from enhanced shrub 
2001
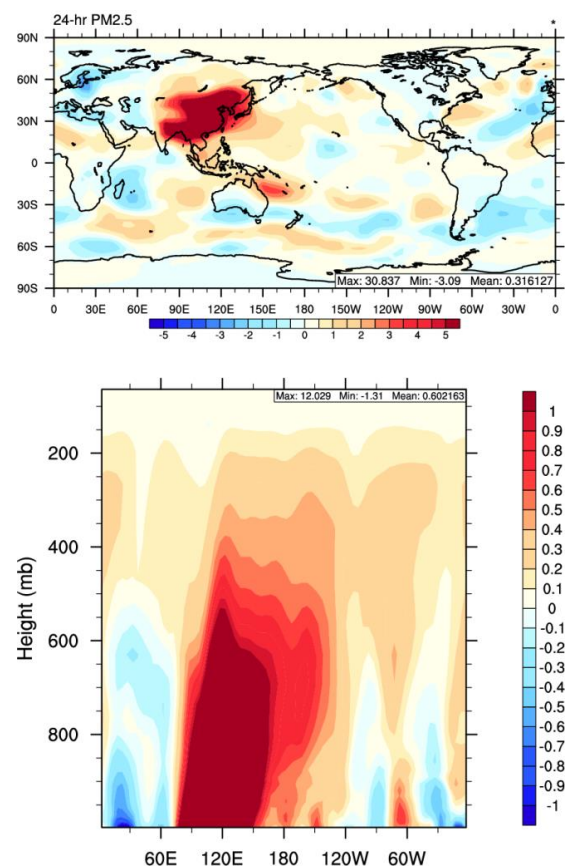

2050
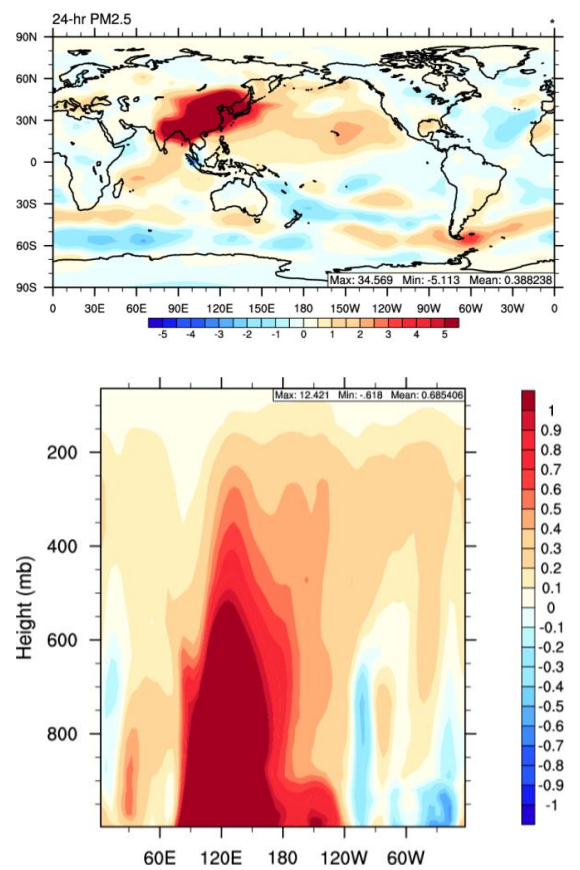

2050_CCO
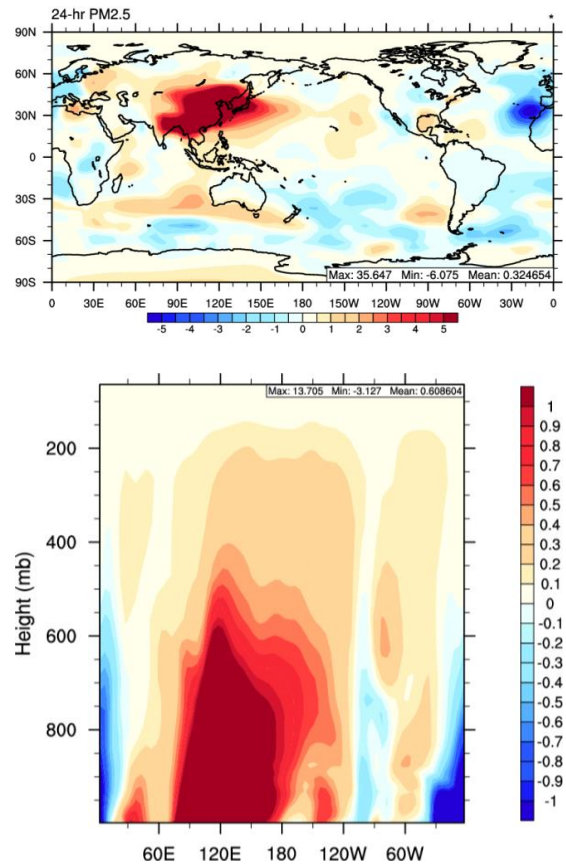

Figure 7. The difference in the spring (MAM) $24 \mathrm{~h}$ average $\mathrm{PM}_{2.5}$ concentration (top) and the mid-latitude ( 24 to $60^{\circ} \mathrm{N}$ ) meridional averaged vertical cross section of $\mathrm{PM}_{2.5}$ (bottom) between the simulations with and without EAAEs for the current (2001) and future (2050 and 2050_CCO) scenarios.

growth in that region (Chapin et al., 2005). EAAEs increase the global average BCTD by $\sim 3.0 \times 10^{-3} \mathrm{~g} \mathrm{~m}^{-2}$ month $^{-1}$ under all scenarios. In all scenarios EAAEs increase Arctic BCTD by $\sim 1 \times 10^{-4}-8 \times 10^{-4} \mathrm{~g} \mathrm{~m}^{-2}$ month $^{-1}(\sim 10$ $80 \%)$. This implies that EAAEs may be a leading contributor to enhanced melting of Arctic snowpack as BC lowers the snowpack albedo (Warren and Wiscombe, 1980; Clarke and Noone, 1985). Additionally, EAAEs contribute to BCTD in both the Tibetan Plateau $\left(1 \times 10^{-3}-3 \times 10^{-2} \mathrm{~g} \mathrm{~m}^{-2}\right.$ month $^{-1}$ or $20-80 \%$ ) and mountainous regions of western North America $\left(1 \times 10^{-3}-1 \times 10^{-2} \mathrm{~g} \mathrm{~m}^{-2}\right.$ month $^{-1}$ or $\left.10-40 \%\right)$, which could impact the melting of snow that is an important reservoir of water for local populations (Hadley et al., 2010; Qian et al., 2011). EAAEs increase the global average HgTD by $\sim 2.0 \times 10^{-8} \mathrm{~g} \mathrm{~m}^{-2}$ month $^{-1}(\sim 48 \%)$, with varying contributions in different regions (e.g., 40-98\% in East Asia and the North Pacific and 20-70\% in the Arctic). In particular, EAAEs increase HgTD in North America by 10 $40 \%$. These results are consistent with the work of Seigneur et al. (2004) and Strode et al. (2008), who reported that Asian anthropogenic emissions contribute 5-36 and $14 \%$ to the $\mathrm{Hg}$ deposition in North America, respectively. The large contributions over all these regions imply that EAAEs-induced HgTD could be a large source of methylmercury, which is bioavailable and can accumulate in rice crops and aquatic life leading to human exposure (Zhang et al., 2010; Meng et al., 2011).

\section{The impact of EAAEs on the climate system}

EAAEs affect regional and global climate under all scenarios. Figure 9 shows the contributions of EAAEs to cloud condensation nuclei $(\mathrm{CCN})$ at a supersaturation of $0.5 \%$, cloud droplet number concentration (CDNC), cloud optical thickness (COT), AOD, ISR, and $\mathrm{JNO}_{2}$ between the simulations with and without EAAEs for 2001, 2050, and 2050_CCO. At a supersaturation of $0.5 \%$, EAAEs increase the global average column CCN by $\sim 3.2 \times 10^{7} \mathrm{~cm}^{-2}$ $(9.5 \%), \sim 1.7 \times 10^{7} \mathrm{~cm}^{-2}(3.5 \%)$, and $\sim 3.6 \times 10^{7} \mathrm{~cm}^{-2}$ $(11.4 \%)$, respectively, where the reduced contribution in 2050 can be attributed to lower aerosol concentrations which result from reductions in primary aerosol emissions. The impacts across all scenarios are the largest in East Asia $\left(5 \times 10^{7}-1.3 \times 10^{9} \mathrm{~cm}^{-2}\right)$, the North Pacific $\left(5 \times 10^{7}\right.$ $\left.1.2 \times 10^{9} \mathrm{~cm}^{-2}\right)$, and portions of North America $\left(5 \times 10^{7}\right.$ $\left.1.5 \times 10^{8} \mathrm{~cm}^{-2}\right)$. The column $\mathrm{CCN}$ can also be reduced by EAAEs, as much as $\sim-3.0 \times 10^{8} \mathrm{~cm}^{-2}$, in regions including western Asia, Europe, and Africa, as a result of decreased aerosol number. Such decreases may result from decreasing nucleation of new particles or slight increases in precipitation over portions of those regions. The general increase in $\mathrm{CCN}$ translates into domain-wide increases of $8.3 \times 10^{4} \mathrm{~cm}^{-2}(11.5 \%), 5.3 \times 10^{4} \mathrm{~cm}^{-2}(8.5 \%)$, and $7.9 \times 10^{4} \mathrm{~cm}^{-2}(19.5 \%)$ in CDNC in 2001,2050 , and 2050_CCO, respectively. CDNC also increases the most 

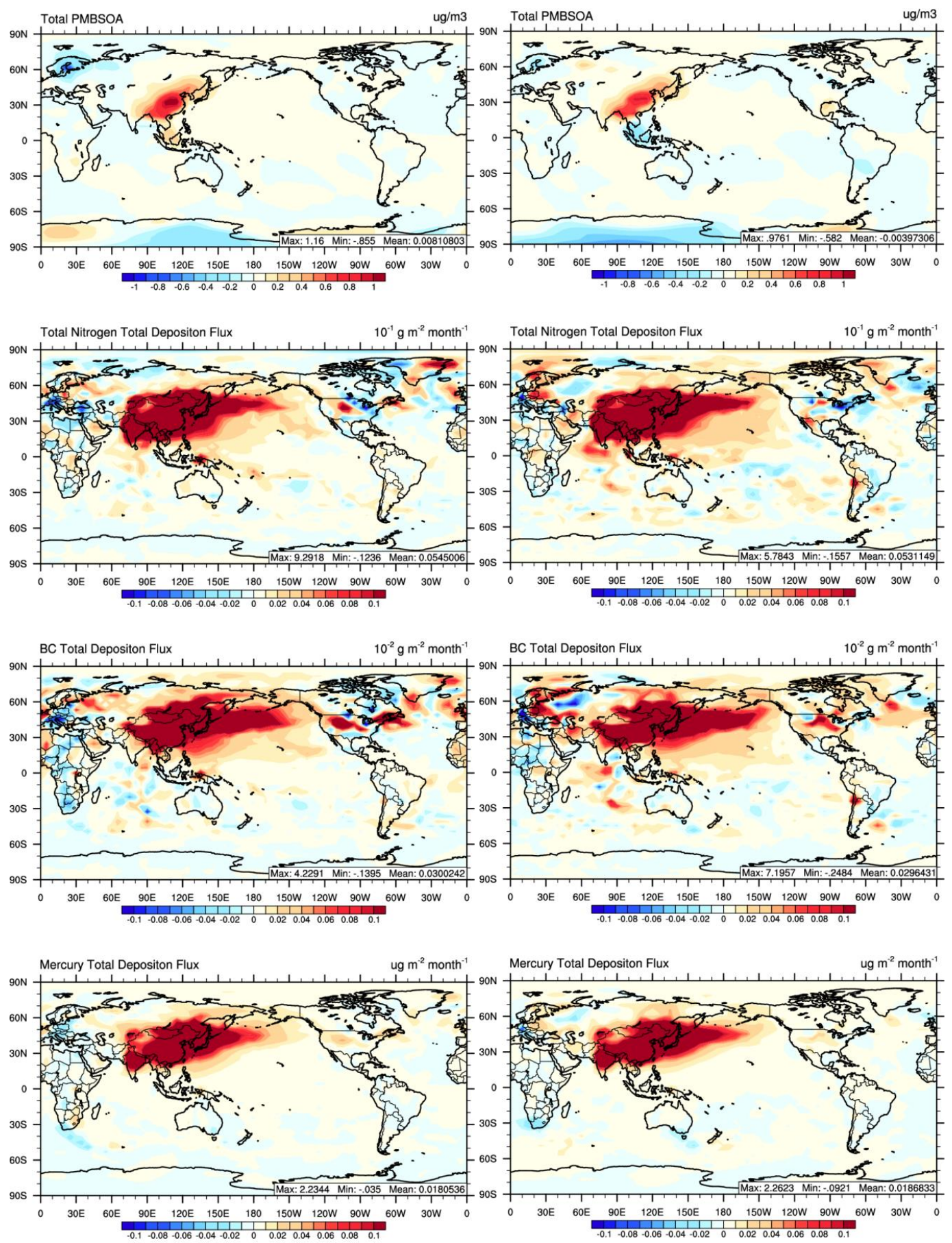

Figure 8. The difference in the spring (MAM) BSOA concentration (row 1), total deposition of total nitrogen (row 2), black carbon aerosol (row 3), and total gaseous and particulate mercury (row 4) between the simulations with and without EAAEs for the current (2001) and future (2050) scenarios.

in East Asia $\left(2.0 \times 10^{5}-2.7 \times 10^{6} \mathrm{~cm}^{-2}\right)$, the North Pacific $\left(2.0 \times 10^{5}-1.0 \times 10^{6} \mathrm{~cm}^{-2}\right)$ and portions of North America $\left(1 \times 10^{5}-4 \times 10^{5} \mathrm{~cm}^{-2}\right)$, but there are certain regions, such as Mexico in 2050, where EAAEs can result in a sizeable de- crease $\left(1.0 \times 10^{5}-3.0 \times 10^{5} \mathrm{~cm}^{-2}\right)$. These decreases are associated with decreases $\left(2-6 \mathrm{~g} \mathrm{~m}^{-2}\right)$ in the cloud liquid water path (LWP). The greatest impact of EAAEs on CDNC occurs in areas with the greatest LWP. In East Asia, these 
2001
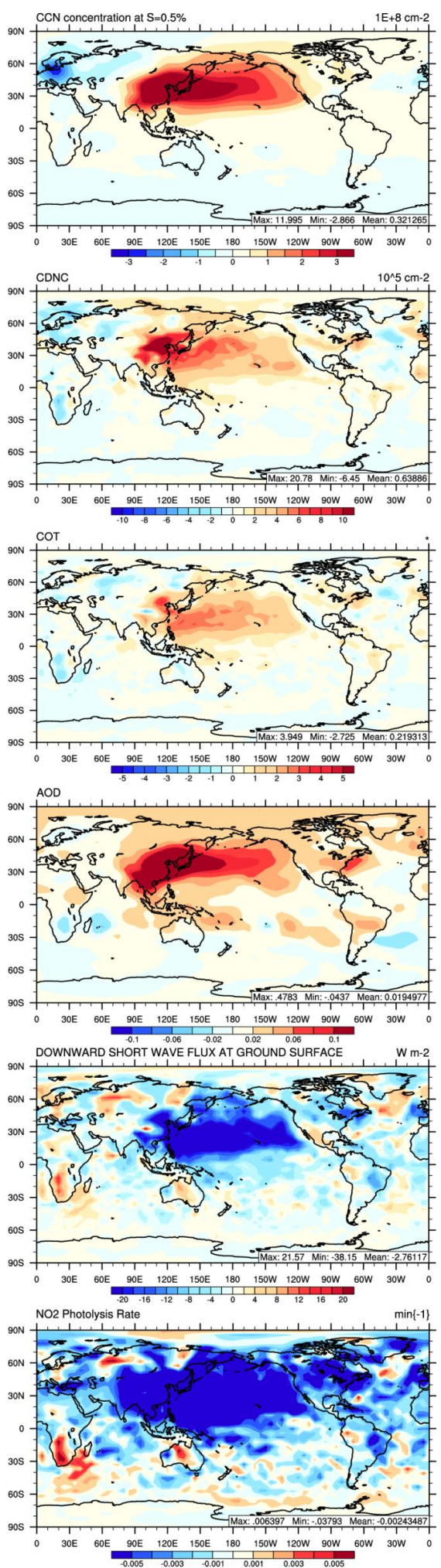

2050
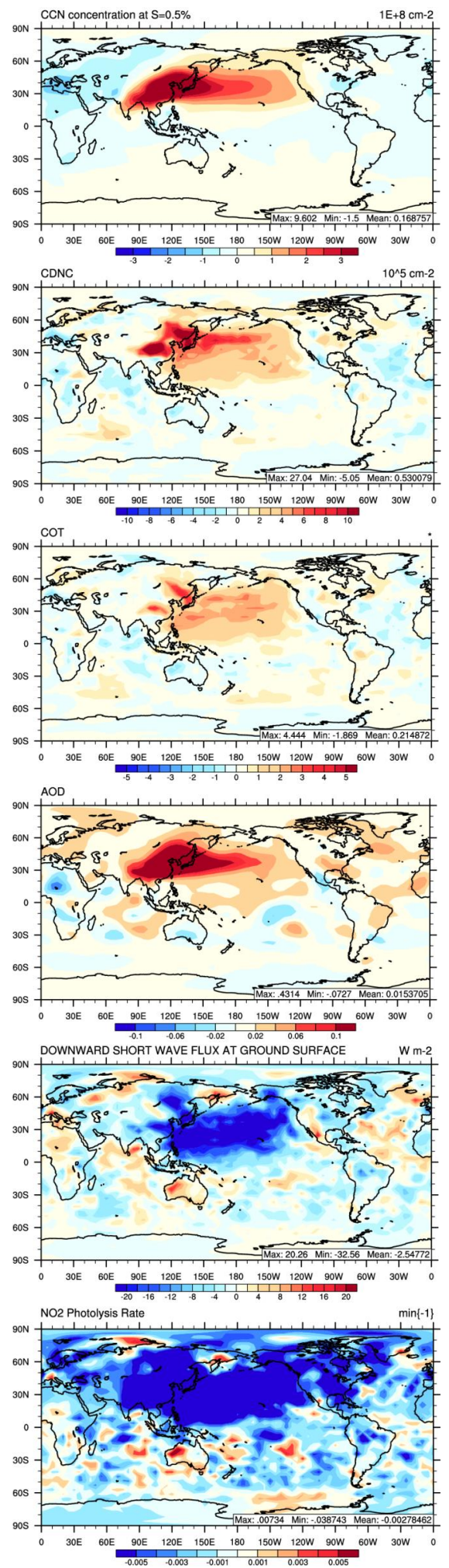

2050_CCO
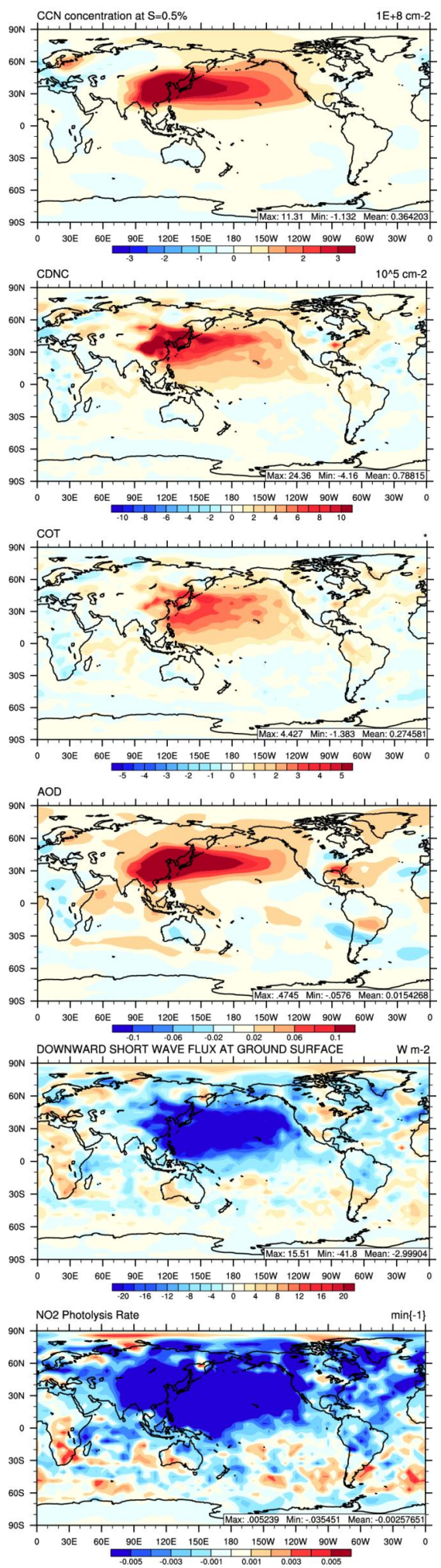

Figure 9. The difference in the spring (MAM) average cloud condensation nuclei (CCN), cloud droplet number concentration (CDNC), cloud optical thickness (COT), aerosol optical depth (AOD), downward solar radiation flux (ISR), and the photolysis rate of $\mathrm{NO}_{2}$ (JNO ${ }_{2}$ ) between the simulations with and without EAAEs for the current (2001), future (2050), and climate change only (2050_CCO) scenarios. 
areas include Southeast Asia and northeastern China. In 2050 and 2050_CCO, these areas of larger LWP migrate to the northeast and the impact on CDNC becomes stronger due to changes in SLP patterns. .

EAAEs increase the global average COT by $\sim 0.2$ with larger increases of 0.5-4.5 in East Asia and its downwind areas in both 2001 and 2050, as shown in Fig. 9. In 2050, the impact on COT is spread more evenly over the North Pacific, while in 2001 the impact is concentrated in the vicinity of the Philippine Sea. This results from changes in the global distribution of cloud LWP between 2050 and 2001, where the LWP increases (by $2-18 \mathrm{~g} \mathrm{~m}^{-2}$ ) in the northernmost portion of the Pacific and Alaska. Also in the subtropical North Pacific, there is also a decrease (by 2 to $6 \mathrm{~g} \mathrm{~m}^{-2}$ ) over the Philippine Sea which weakens the impact in that region. The 2050_CCO scenario experiences the largest impact on COT with a global average impact of 0.3 and a stronger impact (2.0-4.0) over the western North Pacific. This is due to the combination of a greater LWP in the 2050 climate and a greater number of particles to increase the CDNC using the 2001 emissions. Additionally, EAAEs-induced aerosols increase the global average AOD by $\sim 0.02$ but up to 0.5 in East Asia in all cases. In both 2050 and 2050_CCO, the impact on AOD is reduced in the Arctic as a result of the stronger zonal transport over East Asia, which reduces the meridional transport of particles. The COT and AOD increase reduce the ISR by $\sim 2.8 \mathrm{Wm}^{-2}$ in $2001, \sim 2.5 \mathrm{Wm}^{-2}$ in 2050 , and $\sim 3.0 \mathrm{Wm}^{-2}$ in 2050_CCO on global average. The reductions can be as large as $38.2 \mathrm{Wm}^{-2}(18.3 \%), 32.6 \mathrm{Wm}^{-2}$ $(17.8 \%)$, and $41.8 \mathrm{Wm}^{-2}(21.7 \%)$ in East Asia and the North Pacific. Over East Asia, the changes in ISR follow the pattern of CDNC, because increases in CDNC increase COT and result in decreasing ISR. The reduced ISR also leads to a reduction in $\mathrm{JNO}_{2}$ by $\sim 2.4 \times 10^{-3}-2.8 \times 10^{-3} \mathrm{~min}^{-1}$ on global average across all scenarios. The reductions can be larger than $5 \times 10^{-3} \mathrm{~min}^{-1}$ over East Asia, the North Pacific, and North America, indicating that EAAEs reduce photochemistry over the majority of the $\mathrm{NH}$. This primarily reduces the production rate of atomic oxygen gas $(\mathrm{O})$, which then leads to a reduction in the rate of formation of $\mathrm{O}_{3}$ and $\mathrm{OH}$. The amount of $\mathrm{O}_{3}$ is not significantly impacted as changes in precursor amounts and transport are more dominant; however, the $\mathrm{OH}$ level is reduced slightly by $\sim 1 \times 10^{-3} \mathrm{ppt}$ on global average. This slight reduction in oxidants can reduce the production of condensable organic gases and lead to slight reductions in aerosols, such as BSOA, as mentioned previously.

These changes in cloud properties and radiation from EAAEs propagate through the atmosphere and alter the meteorology of the globe. Figure 10 shows the differences in $2 \mathrm{~m}$ temperature, PBLH, and $10 \mathrm{~m}$ wind speed between the simulations with and without EAAEs for 2001, 2050, and 2050_CCO. The aforementioned EAAEs-induced changes result in global cooling of $\sim 0.05^{\circ} \mathrm{C}$ in $2001, \sim 0.02^{\circ} \mathrm{C}$ in 2050 , and $\sim 0.04^{\circ} \mathrm{C}$ in 2050_CCO. In 2001, the tempera- tures decrease by $0.25-1{ }^{\circ} \mathrm{C}$ in East Asia over regions where COT increases, indicating that changes in ISR are the controlling force. In North America, the temperature decreases by $-0.25-2{ }^{\circ} \mathrm{C}$ over northwestern US and western Canada, but increases by $0.25-0.75^{\circ} \mathrm{C}$ over eastern Canada. Both of these regions experience decreased ISR from EAAEs, but the extra cloudiness over eastern Canada enhances the downwelling of long-wave radiation, leading to an average temperature increase. In 2050, the cooling over East Asia from EAAEs is about $0.25-0.75^{\circ} \mathrm{C}$ and there is warming over northeastern China of $0.25-1.25^{\circ} \mathrm{C}$ again from greater downwelling of long-wave radiation. Over North America the cooling is also about $0.25-1^{\circ} \mathrm{C}$, except over Alaska where stronger reductions in ISR decrease the temperature by $0.5-$ $1.5^{\circ} \mathrm{C}$. It is important to note that changes in global $2 \mathrm{~m}$ temperature are not represented in marine environments as the configuration of GU-WRF/Chem simulations used in this work does not contain an ocean model component to simulate the response of sea surface temperatures to changes in radiation. In addition to the surface temperature over the ocean, humidity in the marine boundary layer and large-scale pressure patterns which are controlled by sea surface temperatures will not be impacted by changes in chemistry since sea surface temperatures are static.

Despite their spatial and magnitude discrepancies, all the above impacts have similar trends under both the current and future scenarios with a few exceptions. PBLH is a good example of this exception, since there is no clear trend in the global average with and without EAAEs. In 2001 and 2050, the global average difference with and without EAAEs is a negligible increase of $0.03 \mathrm{~m}$ and decrease of $0.8 \mathrm{~m}$, respectively, while the 2050_CCO simulation shows a more pronounced decrease of $2.5 \mathrm{~m}$. The lack of a clear trend is most likely because PBLH is sensitive not only to changes in the atmosphere but also to the interactions with the underlying land and ocean surface. This sensitivity may also explain why there is no robust model trend in PBLH from climate change (Murazaki and Hess, 2006). However, despite the lack of a clear global trend, there are some stronger regional signals in East Asia, North America, and Scandinavia. The contributions of EAAEs to PBLH over East Asia and North America are complex, but there is a general trend for decreases of 20$100 \mathrm{~m}$ that are spatially co-located with changes in CDNC and COT. The increases in CDNC increase COT, reducing the amount of ISR reaching the surface; this decreases the amount of energy that is exchanged between the atmosphere and the underlying surface and reduces either the sensible heat flux or the latent heat flux and thus reduces the average PBLH. The contribution of EAAEs to PBLH in Scandinavia is not consistent, with an increase of $\sim 10-70 \mathrm{~m}$ in 2001 and a decrease of $\sim 10-30 \mathrm{~m}$ in 2050. The pattern for 2050_CCO is even more complex with an increase over Norway and Sweden and decrease over Finland. In 2001, when Scandinavia experiences lower wind speeds, the increase in PBLH from EAAEs in this scenario has a strong impact and reduces the 

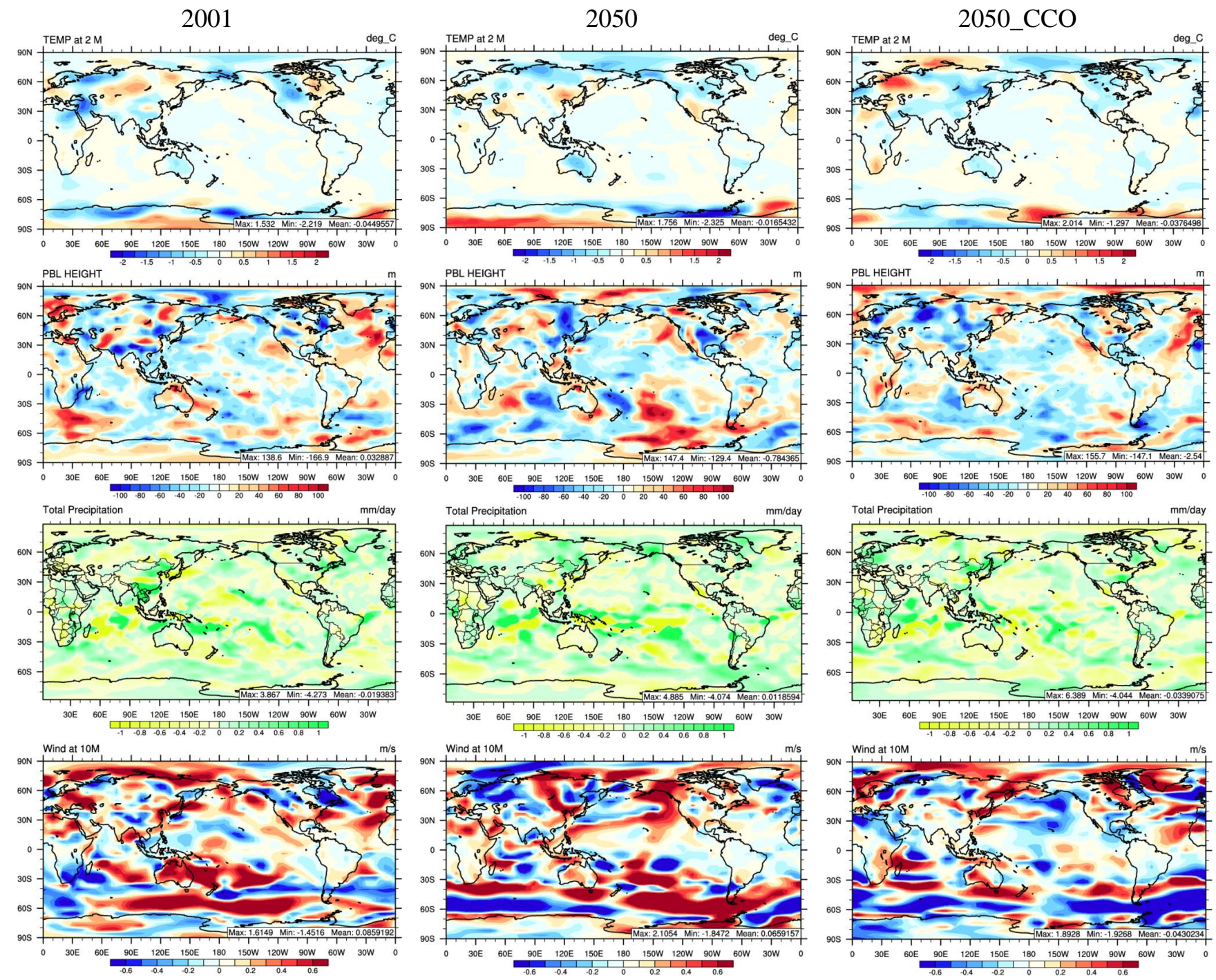

Figure 10. The difference in the spring (MAM) average $2 \mathrm{~m}$ temperature, planetary boundary layer height, total precipitation rate, and $10 \mathrm{~m}$ wind speed between the simulations with and without EAAEs for current (2001), future (2050), and climate change only (2050_CCO).

$\mathrm{PM}_{2.5}$ level at the surface by $\sim 1-3 \mu \mathrm{g} \mathrm{m} \mathrm{m}^{-3}$ (see Figs. 7 and 10). This implies that chemistry feedbacks to meteorology from emission reductions may have the opposite effect on air pollution (i.e., enhance pollution) in some locations under certain conditions. The impact of EAAEs on PR and $10 \mathrm{~m}$ wind speed varies with both emissions and climate scenario. Since the differences between the current and future scenario are relatively small, no robust information can be gleaned.

\section{Concluding remarks}

EAAEs have a strong impact on climate, air quality, and potentially the ecosystems of not only East Asia but other regions downwind under both current and future climate and emission scenarios. This is especially true for the Arctic, which, in addition to the aforementioned impacts, is expected to undergo many changes (e.g., amplified warming, sea ice retreat, and strong ocean acidification) by the latter half of the 21st century (Steinacher et al., 2009; Vavrus et al., 2012). The dominant impacts of EAAEs are to increase chemical concentrations (e.g., $\mathrm{O}_{3}, \mathrm{CO}, \mathrm{PAN}, \mathrm{PM}_{2.5}$ ), total deposition fluxes of chemical species (e.g., total nitrogen, $\mathrm{BC}, \mathrm{Hg}$ ), most cloud/optical variables (e.g., CCN, CDNC, AOD, and COT) but decrease some radiation/photolysis variables (e.g., downward/net shortwave radiation and photolytic rate of $\mathrm{NO}_{2}$ ). Controlling EAAEs can reduce not only the concentrations and depositions of anthropogenic-induced pollutants (by up to $100 \%$ ) but also BSOA (by $10-81 \%$ ). The extent to which these effects can be controlled is beyond the scope of this work as eliminating all emissions from this region is not a realistic possibility and the nonlinear responses in pollutant 
concentrations will vary based on the magnitude of the emission reduction.

The intercontinental transport of Asian pollution will likely play a more important role in the future due to enhanced eastward and northward transport, increased gaseous precursor emissions, and increased temperatures under the climate and emissions scenarios considered in this work. In particular, the $\mathrm{O}_{3}$ and $\mathrm{PM}_{2.5}$ concentrations caused by EAAEs in 2050 will increase by $0.8 \mathrm{ppb}$ and $0.07 \mu \mathrm{g} \mathrm{m}^{-3}$, respectively, on global average and by up to $3-12 \mathrm{ppb}$ and $1-3 \mu \mathrm{g} \mathrm{m}^{-3}$ over some regions. This demonstrates a need for the governments of involved countries to consider the complex interplays between air pollutants and climate to develop integrated emission control strategies for optimal air quality management and climate mitigation.

Similar to other climate change and air quality studies, this study is subject to some limitations and uncertainties. First, this work is based on one current-year simulation and one future-year simulation due to the constraints of computational resources. In Sect. 3 it was illustrated that for T2 and Q2 the climate change signal between 2001 and 2050 is larger than the differences resulting from variability between individual years accounting for model biases. However, internal model variability cannot be completely neglected. This was especially true for model variables whose uncertainty is largely impacted by the choice of model physical parameterizations, such as PR and PBLH that are sensitive to cloud microphysics, cumulus, and PBL parameterizations. This could potentially impact some of the aerosol and trace gas results. For example, the lack of a robust climate change signal in PR could indicate that the wet deposition fluxes of atmospheric pollutants in GU-WRF/Chem are also highly susceptible to internal model variability. However, there is also uncertainty in drawing this conclusion as wet deposition changes do not scale with changes in global precipitation (Fiore et al., 2012). Ideally this work should be expanded in the future to include multi-year averages to help reduce the impact of internal model variability results. This kind of uncertainty could also be reduced by comparing multi-model ensembles following the work of Fiore et al. (2009) but with a broader focus than $\mathrm{O}_{3}$. Second, the use of the "brute force" method may be another source of uncertainty as this method is more susceptible to model noises than adjoint or tagged tracer methods (Brandt et al., 2012). Therefore, possible future work may include adopting the nonlinear tagged tracer method employed in Brandt et al. (2012), as it accounts for nonlinearities and is not as sensitive to model noise. Third, other uncertainties result from simplifying assumptions in GU-WRF/Chem, such as neglecting the impact of changing vegetation on dry deposition and future land use and land cover changes. These two processes may have a strong impact on air quality in certain regions since losses in soil moisture have been shown to greatly reduce $\mathrm{O}_{3}$ deposition from vegetation wilting in southern Europe (Andersson and Engardt, 2010) and changes in land use have been shown to impact $\mathrm{O}_{3}$ by up to $20 \%$ under the SRES A2 scenario (Fiore et al., 2012). $\mathrm{O}_{3}$ and $\mathrm{PM}_{2.5}$ formation are also tied to changes in biogenic emissions, whose future changes may be highly uncertain. The use of a dynamic vegetation model has been shown to reduce isoprene emissions by $39 \mathrm{Tg} \mathrm{yr}^{-1}$, which can reduce $\mathrm{O}_{3}$ by $5-30 \mathrm{ppb}$ in certain regions (Sanderson et al., 2003). The effect of $\mathrm{CO}_{2}$ inhibition on isoprene emissions has been shown to be important, especially in non-polluted regions (Young et al., 2009), but this effect is neglected in the MEGAN2 model used in this work. Finally, future changes in $\mathrm{O}_{3}$ are sensitive to the treatment of organic nitrates (Ito et al., 2009; Weaver et al., 2009), which are not treated explicitly in this version of GU-WRF/Chem. The effect of changing climate and emissions on $\mathrm{PM}_{2.5}$ is more uncertain than that of $\mathrm{O}_{3}$ since there are large uncertainties in emissions of primary species and secondary formation. The largest emission uncertainty is from wildfire emissions, as they will be tied to changes in the frequency and duration of heat waves and drought conditions (Jacob and Winner, 2009; Fiore et al., 2012). The uncertainties in secondary formation are related to both changes in emissions of precursors and changes in future oxidation capacity. Changes in precursor emissions may indicate a change in the relative concentrations of the various $\mathrm{PM}_{2.5}$ species, since declining $\mathrm{SO}_{2}$ emissions predicted in many future scenarios may allow for the possibility of enhanced nitrate formation (Fiore et al., 2012) or the dominance of organic aerosols (Tagris et al., 2007). These changes are tied to the future oxidant budget since increase water vapor will likely increase the formation of $\mathrm{OH}$ and $\mathrm{H}_{2} \mathrm{O}_{2}$, which may lead to greater conversion of $\mathrm{SO}_{2}$ to sulfate and greater secondary organic aerosol (SOA) formation (Tagris et al., 2007; Jacob and Winner, 2009). The reduction of these uncertainties will require future model development and targeting sensitivity tests or adjoint model studies to probe how $\mathrm{PM}_{2.5}$ responds to changing primary and precursor emissions and future oxidation from climate change.

\section{The Supplement related to this article is available online at doi:10.5194/acp-14-9379-2014-supplement.}

Acknowledgements. This work is supported by United States Environmental Protection Agency Science to Achieve Results program grant no. R83337601 and the National Sciences Foundation (NSF)/United State Department of Agriculture Earth System Modeling program grant no. AGS-1049200 at NCSU and 201267003-30192 at the University of Chicago/ANL. Thanks are due to Mark Richardson at Caltech and William C. Skamarock at NCAR, for developing global WRF on which the GU-WRF/Chem is based; Louisa Emmons and Francis Vitt at NCAR for providing CAM4 and MOZART4 emissions. Thanks are also due to Shuai Zhu, a former postdoc researcher at NCSU, for adding the deposition fluxes in the model output.

Edited by: Y. Cheng 


\section{References}

Andersson, C., and Engardt, M.: European ozone in a future climate: Importance of changes in dry deposition and isoprene emissions, J. Geophys. Res., 115, D02303, doi:10.1029/2008JD011690, 2010.

Anenberg, S. C., West, J. J., Fiore, A. M., Jaffe, D. A., Prather, M. J., Bergmann, D., Cuvelier, K., Dentener, F. J., Duncan, B. N., Gauss, M., Hess, P., Jonson, J. E., Lupu, A., Mackenzie, I. A., Marmer, E., Park, R. J., Sanderson, M. G., Schultz, M., Shindell, D. T., Szopa, S., Vivanco, M. G., Wild, O., and Zeng, G.: Intercontinental impacts of ozone pollution on human mortality, Environ. Sci. Technol., 43, 6482-6487, doi:10.1021/es900518z, 2009.

Bader, D., Achuta Rao, K., Covey, C., Doutriaux, C., Fiorino, M., Gleckler, P., Phillips, T., Sperber, K., and Taylor, K.: An appraisal of coupled climate model simulations, Lawrence Livermore National Laboratory, Livermore, CA, Open File Rep. UCRL-TR202550, 197 pp., 2004.

Bey, I., Jacob, D. J., Logan, A., and Yantosca, R. M.: Asian chemical outflow to the Pacific in spring: Origins, pathways, and budgets, J. Geophys. Res., 106, 23097- 23113, doi:10.1029/2001JD000806, 2001.

Brandt, J., Silver, J. D., Frohm, L. M., Geels, C., Gross, A., Hansen, A. B., Hansen, K. M., Hedegaard, G. B., Skjoth, C.A., Villadsen, H., Zare, A., and Christensen, J. H.: An integrated model study for Europe and North America using the Danish Eulerian Hemispheric Model with focus on intercontinental transport of air pollution, Atmos. Environ., 53, 156-176, doi:10.1016/j.atmosenv.2012.01.011, 2012.

Carlton, A. G., Pinder, R. W., Bhave, P. V., and Pouliot, G. A.: To what extent can biogenic SOA be controlled?, Environ. Sci. Technol., 44, 3376-3380, doi:10.1021/es903506b, 2010.

Chapin III, F. S., Sturm, M., Serreze, M. C., McFadden, J. P., Key, J. R., Lloyd, A. H., McGuire, A. D., Rupp, T. S., Lynch, A. H., Schimel, J. P., Beringer, J., Chapman, W. L., Epstein, H. E., Euskirchen, E. S., Hinzman, L. D., Jia, G., Ping, C.-L., Tape, K. D., Thompson, C. D. C., Walker, D. A., and Welker, J. M.: Role of Land-Surface Changes in Arctic Summer Warming, Science, 310, 657-660, doi:10.1126/science.1117368, 2005.

Clarke, A. D. and Noone, K. J.: Soot in the Arctic snowpack: A cause for perturbations in radiative transfer, Atmos. Environ., 19, 2045-2053, 1985.

Cooper, O. R., Forester, C., Parrish, D., Trainer, M., Dunlea, E., Ryerson, T., Hubler, G., Fehsenfeld, F., Nicks, D., Holloway, J., de Gouw, J., Warneke, C., Roberts, J. M., Flocke, F., and Moody, J.: A case study of transpacific warm conveyor belt transport: Influence of merging airstreams on trace gas import to North America, J. Geophys. Res., 109, D23S08, doi:10.1029/2003JD003624, 2004.

Doherty, R. M., Wild, O., Shindell, D. T., Zeng, G., MacKenzie, I. A., Collins, W. J., Fiore, A. M., Stevenson, D. S., Dentener, F., Schultz, M. G., Hess, P., Derwent, R. G., and Keating, T. J.: Impacts of climate change on surface ozone and intercontinental ozone pollution: A multi-model study, J. Geophys. Res. Atmos., 118, 3744-3763, doi:10.1002/jgrd.50266, 2013.

Duce, R. A., LaRoche, J., Altieri, K., Arrigo, K. R., Baker, A. R., Capone, D. G., Cornell, S., Dentener, F., Galloway, J., Ganeshram, R. S., Geider, R. J., Jickells, T. Kuypers, M. M., Langlois, R., Liss, P. S., Liu, M., Middelburg, J. J., Moore, C.
M., Nickovic, S., Oschlies, Pedersen, T., Prospero, J., Schlitzer, R., Seitzinger, S., Sorensen, L. L., Uematsu, M., Ulloa, O., Voss, M., Ward, B., and Zamora, L.: Impacts of atmospheric anthropogenic nitrogen on the open ocean, Science, 320, 893-897, doi:10.1126/science.1150369, 2008.

Fiore, A. M., Dentener, F. J., Wild, O., Cuvelier, C., Schultz, M. G., Hess, P., Textor, C., Schulz, M., Doherty, R. M., Horowitz, L. W., MacKenzie, I. A., Sanderson, M. G., Shindell, D. T., Stevenson, D. S., Szopa, S., Van Dingenen, R., Zeng, G., Atherton, C., Bergmann, D., Bey, I., Carmichael, G., Collins, W. J., Duncan, B. N., Faluvegi, G., Folberth, G., Gauss, M., Gong, S., Hauglustaine, D., Halloway, T., Isaksen, I.S.A., Jacob, D. J., Jonson, J. E., Kaminski, J. W., Keating, T. J., Lupu, A., Marmer, E., Montanaro, V., Park, R.J., Pitari, G., Pringle, K. J., Pyle, J. A., Schroeder, S., Vivanco, M. G., Wind, P., Wojcik, G., Wu, S., and Zuber, A.: Multimodel estimates of intercontinental sourcereceptor relationships for ozone pollution, J. Geophys. Res., 114, D04301, doi:10.1029/2008JD010816, 2009.

Fiore, A.M., Naik, V., Spracklen, D. V., Steiner, A., Unger, N., Prather, M., Bergmann, D., Cameron-Smith, P. J., Cionni, I., Collins, W. J., Dalsoren, S., Eyring, V., Folberth, G. A., Ginoux, P., Horowitz, L. W., Josse, B., Lamarque, J.-F., MacKenzie, I. A., Nagashima, T., O'Connor, F. M., Right, M., Rumbold, S. T., Shindell, D. T., Skeie, R. B., Sudo, K., Szopa, S., Takemura, T., and Zeng, G.: Global air quality and climate, Chem. Soc. Rev., 41, 6663-6683, doi:10.1039/C2CS35095E, 2012.

Fisher, J. A., Jacob, D. J., Purdy, M. T., Kopacz, M., Le Sager, P., Carouge, C., Holmes, C. D., Yantosca, R. M., Batchelor, R. L., Strong, K., Diskin, G. S., Fuelberg, H. E., Holloway, J. S., Hyer, E. J., McMillan, W. W., Warner, J., Streets, D. G., Zhang, Q., Wang, Y., and Wu, S.: Source attribution and interannual variability of Arctic pollution in spring constrained by aircraft (ARCTAS, ARCPAC) and satellite (AIRS) observations of carbon monoxide, Atmos. Chem. Phys., 10, 977-996, doi:10.5194/acp10-977-2010, 2010.

Gong, S. L., Barrie, L. A., and Blanchet, J.-P.: Modeling sea-salt aerosols in the atmosphere: 1. Model development, J. Geophys. Res., 102, 3805-3818, 1997.

Guenther, A., Karl, T., Harley, P., Wiedinmyer, C., Palmer, P. I., and Geron, C.: Estimates of global terrestrial isoprene emissions using MEGAN (Model of Emissions of Gases and Aerosols from Nature), Atmos. Chem. Phys., 6, 3181-3210, doi:10.5194/acp-63181-2006, 2006.

Hadley, O. L., Ramanathan, V., Carmichael, G. R., Tang, Y., Corrigan, C. E, Roberts, G. C., and Mauger, G. S.: Trans-Pacific transport of black carbon and fine aerosols (D $<2.5 \mathrm{~mm}$ ) into North America, J. Geophys. Res., 112, D05309, doi:10.1029/2006JD007632, 2007.

Hadley, O. L., Corrigan, C. E., Kirchstetter, T. W., Cliff, S. S., and Ramanathan, V.: Measured black carbon deposition on the Sierra Nevada snow pack and implication for snow pack retreat, Atmos. Chem. Phys., 10, 7505-7513, doi:10.5194/acp-10-75052010, 2010.

Henze, D. K., Seinfeld, J. H., and Shindell, D. T.: Inverse modeling and mapping US air quality influences of inorganic $\mathrm{PM}_{2.5}$ precursor emissions using the adjoint of GEOS-Chem, Atmos. Chem. Phys., 9, 5877-5903, doi:10.5194/acp-9-5877-2009, 2009. 
Hess, P. G., and Vukicevic T.: Intercontinental transport, chemical transformations, and baroclinic systems, J. Geophys. Res., 108, 4354, doi:10.1029/2002JD002798, 2003.

Husar, R. B., Tratt, D. M., Schichtel, B. A., Falke, S. R., Li, F., Jaffe, D., Gasso, S., Gill, T., Laulainen, N. S., Lu, F., Reheis, M. C., Chun, Y., Westphal, D., Holben, B. N., Gueymard, C., McKendry, I., Kuring, N., Feldman, G. C., McClain, C., Frouin, R. J., Merrill, J., DuBois, D., Vignola, F., Murayama, T., Nickovic, S., Wilson, W. E., Sassen, K., Sugimoto, N., and Malm, W. C.: Asian dust events of April 1998, J. Geophys. Res., 106, 18317-18330, doi:10.1029/2000JD900788, 2001.

Intergovernmental Panel on Climate Change (IPCC), Special Report on Emission Scenarios (SRES), A Special Report of Working Group III of the Intergovernmental Panel on Climate Change, edited by N. Nakicenovic and R. Swart, 570 pp., Cambridge Univ. Press, Cambridge, U. K., 2000.

Ito, A., Sillman, S., and Penner, J. E.: Global chemical transport model study of ozone response to changes in chemical kinetics and biogenic volatile organic compounds emissions due to increasing temperatures: Sensitivities to isoprene nitrate chemistry and grid resolution, J. Geophys. Res., 114, D09301, doi:10.1029/2008JD011254, 2009.

Jacob, D. J., Logan, J. A., and Murti, P. P.: Effect of rising Asian emission on surface ozone in the United States, Geophys. Res. Lett., 26, 2175-2178, doi:10.1029/1999GL900450, 1999.

Jacob, D. J. and.Winner, D. A.: Effect of climate change on air quality, Atmos. Environ., 43, 51-63, doi:10.1016/j.atmosenv.2008.09.051, 2009.

Jaffe, D. A., Anderson, T., Covert, D., Kotchenruther, R., Trost, B., Danielson, J., Simpson, W., Berntsen, T., Karlsdottir, S., Blake, D., Harris, J., Carmichael, G., and Uno, I.: Transport of Asian air pollution to North America, Geophys. Res. Lett., 26, 711-714, doi:10.1029/1999GL900100, 1999.

Jaffe, D. A., McKendry, I., Anderson, T., and Price H.: Six "new" episodes of trans-Pacific transport of air pollutants, Atmos. Environ., 37, 391-404, doi:10.1016/S1352-2310(02)00862-2, 2003.

John, V. O. and Soden B. J.: Temperature and humidity biases in global climate models and their impact on climate feedbacks, Geophys. Res. Lett., 34, L18794, doi:10.1029/2007GL030429, 2007.

Jonson, J. E., Stohl, A., Fiore, A. M., Hess, P., Szopa, S., Wild, O., Zeng, G., Dentener, F. J., Lupu, A., Schultz, M. G., Duncan, B. N., Sudo, K., Wind, P., Schulz, M., Marmer, E., Cuvelier, C., Keating, T., Zuber, A., Valdebenito, A., Dorokhov, V., De Backer, H., Davies, J., Chen, G. H., Johnson, B., Tarasick, D. W., Stübi, R., Newchurch, M. J., von der Gathen, P., Steinbrecht, W., and Claude, H.: A multi-model analysis of vertical ozone profiles, Atmos. Chem. Phys., 10, 5759-5783, doi:10.5194/acp-10-5759-2010, 2010.

Kriegler, E., O’Neill, B. C., Hallegatte, S., Kram, T., Lempert, R. J., Moss, R. H., and Wilbanks, T.: The need for and use of socio-economic scenarios for climate change analysis: A new approach based on shared socio-economic pathways, Global Environ. Chang., 22, 807-822, 2012.

Lau, K.-M. and Kim, K.-M.: Observational relationships between aerosol and Asian monsoon rainfall, and circulation, Geophys. Res. Lett., 33, L21810, doi:10.1029/2006GL027546, 2006a.
Lau, K. M., Kim, M. K., and Kim, K. M.: Asian monsoon anomalies induced by aerosol direct effects, Clim. Dyn., 26, 855-864, doi:10.1007/s00382-006-0114-z, 2006b.

Leibensperger, E. M., Mickley, L. J., Jacob, D. J., and Barrett, S. R. H.: Intercontinental influence of NOx and $\mathrm{CO}$ on particulate matter air quality, Atmos. Environ., 45, 3318-3324, doi:10.1016/j.atmosenv.2011.02.023, 2011.

Lin, J.-T., Wuebbles, J. T., and Liang, X.-Z.: Effects of intercontinental transport on surface ozone over the United States: Present and future assessment with a global model, Geophys. Res. Lett., 35, L02805, doi:10.1029/ 2007GL031415, 2008.

Liu, H., Jacob, D. J., Bey, I., Yantosca, R. M., Duncan, B. N., and Sachse, G. W.: Transport pathways for Asian pollution outflow over the Pacific: Interannual and seasonal variations, J. Geophys. Res., 108, 8786, doi:10.1029/2002JD003102, 2003.

Liu, J., Mauzerall, D. L., and Horowitz, L. W.: Source-receptor relationships between East Asian sulfur dioxide emissions and Northern Hemisphere sulfate concentrations, Atmos. Chem. Phys., 8, 3721-3733, doi:10.5194/acp-8-3721-2008, 2008.

Liu, J., Mauzerall, D. L., and Horowitz, L. W.: Evaluating inter-continental transport of fine aerosol 2) global health impact, Atmos. Environ., 43, 4339-4347, doi:10.1016/j.atmosenv.2009.05.032, 2009.

Masui, T., K., Hijioka, Y., Kinoshita, T., Nozawa, T., Ishiwatari, S., Kato, E. Shukla, P. R., Yamaga, Y., and Kainuma, M.: An emission pathway for stabilization at $6 \mathrm{Wm}^{-2}$ radiative forcing, Clim. Chang., 109, 59-76, doi:10.1007/s10584-011-0150-5, 2011.

Meng, B., Feng, X., Qiu, G., Liang, P., Li, P, Chen, C., and Shang, L.: The process of methylmercury accumulation in rice (Oryza sativa L.), Environ. Sci. Technol., 45, 2711-2717, doi:10.1021/es103384v, 2011.

Menon, S., Hansen, J., Nazarenko, L., and Luo, Y.: Climate effects of black carbon aerosols in India and China, Science, 297, 22502253, doi:10.1126/science.1075159, 2002.

Moss, R. H., Edmonds, J. A, Hibbard, K. A, Manning, M. R., Rose, S. K., van Vuuren, D. P., Carter, T. R., Emori, S., Kainuma, M., Kram, T., Meehl, G. A, Mitchell, J. F. B., Nakicenovic, N., Riahi, K., Smith, S. J., Stouffer, R. J., Thomson, A. M., Weyant, J. P.,. and Wilbanks, T. J.: The next generation of scenarios for climate change research and assessment, Nature, 463, 747-56, 2010.

Murazaki, K. and Hess, P.: How does climate change contribute to surface ozone change over the United States?, J. Geophys. Res., 111, D05301, doi:10.1029/2005JD005873, 2006.

Nakicenovic, N., Davidson, O., Davis, G., Grubler, A., Kram, T., La Rovere, E.L., Metz, B., Morita, T., Pepper, W., Pitcher, H., Sankovski, A., Shukla, P., Swart, R., Watson, R., and Dadi, Z.: Emissions Scenarios: A Special Report of Working Group III of the Intergovernmental Panel on Climate Change, Cambridge University Press, New York, 2001.

O’Dowd, C., Smith, M. H., Consterdine, J. E., and Lowe, J. A.: Marine aerosol, sea-salt, and the marine sulphur cycle: a short review, Atmos. Environ., 31, 73-80, 1997.

Park, R. J., Jacob, D. J., Field, B. D., Yantosca, R. M., and Chin, M.: Natural and transboundary pollution influences on sulfate-nitrate-ammonium aerosols in the United States: Implications for policy, J. Geophys. Res., 109, D15204, doi:10.1029/2003JD004473, 2004.

Pfister, G. G., Emmons, L. K., Hess, P. G., Lamarque, J.-F., Thompson, A. M., and Yorks, J. E.: Analysis of the Sum- 
mer 2004 ozone budget over the United States using Intercontinental Transport Experiment Ozonesonde Network Study (IONS) observations and Model of Ozone and Related Tracers (MOZART-4) simulations, J. Geophys. Res., 113, D23306, doi:10.1029/2008JD010190, 2008.

Qian, Y., Leung, L. R., Ghan, S. J., and Giorgi, F.: Regional climate effects of aerosols over China: modeling and observation, Tellus, 55B, 914-934, 2003.

Qian, Y., Kaiser, D. P., Leung, L. R., and Xu, M.: More frequent cloud-free sky and less surface solar radiation in China from 1955 to 2000, Geophys. Res. Lett., 33, L01812, doi:10.1029/2005GL024586, 2006.

Qian, Y., Wang, W., Leung, L. R., and Kaiser, D. P.: Variability of solar radiation under cloud-free skies in China: The role of aerosols, Geophys. Res. Lett., 34, L12804, doi:10.1029/2006GL028800, 2007.

Qian, Y., Flanner, M. G., Leung, L. R., and Wang, W.: Sensitivity studies on the impacts of Tibetan Plateau snowpack pollution on the Asian hydrological cycle and monsoon climate, Atmos. Chem. Phys., 11, 1929-1948, doi:10.5194/acp-11-19292011, 2011

Ravetta, F., Ancellet, G., Colette, A., and Schlager, H.: Longrange transport and tropospheric ozone variability in the western Mediterranean region during the Intercontinental Transport of Ozone and Precursors (ITOP-2004) campaign, J. Geophys. Res., 112, D10S46, doi:10.1029/2006JD007724, 2007.

Reidmiller, D. R., Fiore, A. M., Jaffe, D. A., Bergmann, D., Cuvelier, C., Dentener, F. J., Duncan, B. N., Folberth, G., Gauss, M., Gong, S., Hess, P., Jonson, J. E., Keating, T., Lupu, A., Marmer, E., Park, R., Schultz, M. G., Shindell, D. T., Szopa, S., Vivanco, M. G., Wild, O., and Zuber, A.: The influence of foreign vs. North American emissions on surface ozone in the US, Atmos. Chem. Phys., 9, 5027-5042, doi:10.5194/acp-9-5027-2009, 2009.

Riahi, K., Rao, S., Krey, V., Cho, C., Chirkov, V., Fischer, G., Kindermann, G., Nakicenovic, N., and Rafaj, P.: RCP 8.5-A scenario of comparatively high greenhouse gas emissions, Clim. Chang., 109, 33-57, doi:10.1007/s10584-011-0149-y, 2011.

RIVM (National Institute for Public Health and the Environment), The IMAGE 2.2 Implementation of the SRES Scenarios [CDROM], RIVM Publication 481508018, Bilthoven, Netherlands, 2001.

Roberts, G., Mauger, G., Hadley, O., and Ramanathan, V.: North American and Asian aerosols over the eastern Pacific Ocean and their role in regulating cloud condensation nuclei, J. Geophys. Res., 111, D13205, doi:10.1029/2005JD006661, 2006.

Sanderson, M. G., Jones, C. D., Collins, W. J., Johnson, C. E., and Derwent, R. G.: Effect of climate change on isoprene emissions and surface ozone levels, Geophys. Res. Lett., 30, 1936, doi:10.1029/2003GL017642, 2003.

Sanderson, M. G., Dentener, F. J., Fiore, A. M., Cuvelier, C., Keating, T. J., Zuber, A., Atherton, C. S., Bergmann, D. J., Diehl, T., Doherty, R. M., Duncan, B. N., Hess, P., Horowitz, L. W., Jacob, D. J., Jonson, J.-E., Kaminski, J. W., Lupu, A., MacKenzie, I. A., Mancini, E., Marmer, E., Park, R., Pitari, G., Prather, M. J., Pringle, K. J., Schroeder, S., Schultz, M. G., Shindell, D. T., Szopa, S., Wild, O., and Wind, P.: A multi-model study of the hemispheric transport and deposition of oxidized nitrogen, Geophys. Res. Lett., 35, L17815, doi:10.1029/2008GL035389, 2008.
Schindler, D. W. and Bayley, S. E.: The biosphere as an increasing sink for atmospheric carbon: Estimates from increased nitrogen deposition, Glob. Biogeochem. Cycles, 7, 717-733, 1993.

Seigneur, C., Vijayaraghavan, K., Lohman, K., Karamchandani, P., and Scott C.: Global source attribution for mercury deposition in the United States, Environ. Sci. Technol., 28, 555-569, doi:10.1021/es034109t, 2004

Shaw, P.: Application of aerosol speciation data as an in situ dust proxy for validation of the Dust Regional Atmospheric Model (DREAM), Atmos. Environ., 42, 7304-7309, doi:10.1016/j.atmosenv.2008.06.018, 2008.

Shindell, D. T., Chin, M., Dentener, F., Doherty, R. M., Faluvegi, G., Fiore, A. M., Hess, P., Koch, D. M., MacKenzie, I. A., Sanderson, M. G., Schultz, M. G., Schulz, M., Stevenson, D. S., Teich, H., Textor, C., Wild, O., Bergmann, D. J., Bey, I., Bian, H., Cuvelier, C., Duncan, B. N., Folberth, G., Horowitz, L. W., Jonson, J., Kaminski, J. W., Marmer, E., Park, R., Pringle, K. J., Schroeder, S., Szopa, S., Takemura, T. Zeng, G., Keating, T. J., and Zuber, A.: A multi-model assessment of pollution transport to the Arctic, Atmos. Chem. Phys., 8, 5353-5372, doi:10.5194/acp-8-5353-2008, 2008.

Steinacher, M., Joos, F., Frölicher, T. L., Plattner, G.-K., and Doney, S. C.: Imminent ocean acidification in the Arctic projected with the NCAR global coupled carbon cycle-climate model, Biogeosciences, 6, 515-533, doi:10.5194/bg-6-5152009, 2009.

Stohl, A., Eckhardt, S., Forster, C., James, P., and Spichtinger, $\mathrm{N}$.: On the pathways and timescales of intercontinental air pollution transport, J. Geophys. Res., 107, 4684, doi:10.1029/2001JD001396, 2002.

Strode, S. A., Jaegle, L., Jaffe, D. A., Swartzendruber, P C., Selin, N. E., Holmes, C., and Yantosca, R. M.: TransPacific transport of mercury, J. Geophys. Res., 113, D15305, doi:10.1029/2007JD009428, 2008

Sudo, K. and Akimoto, H.: Global source attribution of tropospheric ozone: Long-range transport from various source regions, J. Geophys. Res., 112, D12302, doi:10.1029/2006JD007992, 2007.

Tagaris, E., Manomaiphiboon, K., Liao, K.-I., Leung, L. R., Woo, J.-H., He, S., Amar, P., and Russell, A.G.: Impacts of global climate change and emissions on regional ozone and fine particulate matter concentrations over the United States, J. Geophys.Res. 112, D14312, doi:10.1029/2006JD008262, 2007.

Takigawa, M., Sudo, K., Akimoto, H., Kita, K., Takegawa, N., Kondo, Y., and Takahashi, M.: Estimation of the contribution of intercontinental transport during the PEACE campaign by using a global model, J. Geophys. Res., 110, D21313, doi:10.1029/2005JD006226, 2005.

TF HTAP - Task Force on Hemispheric Transport of Air Pollution: Hemispheric Transport of Air Pollution 2010, Part A: Ozone and Particulate Matter, Air Pollut. Stud., 17, edited by: Dentener, F., Keating, T. J., and Akimoto, H., United Nations Economic Commission for Europe, Geneva, Switzerland, available at: http://www.htap.org (last access: August 2013), 2011.

Tian, B., Fetzer, E. J., Kahn, B. H., Teixerira, J., Manning, E., and Hearty, T.: Evaluating CMIP5 models using AIRS tropospheric air temperature and specific humidity climatology, J. Geophys. Res., doi:10.1002/jgrd.50117, 2013.

van Vuuren, D., Riahi, K., Moss, R., Edmonds, J., Allison, T., Nakicenovic, N., Kram, T., Berkhout, F., Swart, R., Janetos, A., Rose, 
S. K., and Arnell, N.: A proposal for a new scenario framework to support research and assessment in different climate research communities, Global Environ. Chang., 22, 21-35, 2012.

Vavrus, S. J., Holland, M. M., Jahn, A., Bailey, D. A., and Blazey, B. A.: Twenty-First-Century Arctic climate change in CCSM4, J. Climate, 25, 2696-2710, doi:10.1175/JCLI-D-11-00220.1, 2011.

Wang, K., Zhang, Y., Jang, C., Phillips, S., and Wang, B.: Modeling intercontinental air pollution transport over the transPacific region in 2001 using the Community Multiscale Air Quality modeling system, J. Geophys. Res., 114, D04307, doi:10.1029/2008JD010807, 2009.

Wang, K., Zhang, Y., Nenes, A., and Fountoukis, C.: Implementation of dust emission and chemistry into the Community Multiscale Air Quality modeling system and initial application to an Asian dust storm episode, Atmos. Chem. Phys., 12, 1020910237, doi:10.5194/acp-12-10209-2012, 2012.

Warren, S. G. and Wiscombe, W. J.: A model for the spectral albedo of snow. II: Snow containing atmospheric aerosols, J. Atmos. Sci., 37, 2734-2745, 1980.

Weaver, C. P., Liang, X.-Z., Zhu, J., Adams, P.J., Amar, P., Avise, J., Caughey, M., Chen, J., Cohen, R. C., Cooter, E., Dawson, J. P., Gilliam, R., Gilliland, A., Goldstein, A. H., Grambsch, A., Grand, D., Guenther, A., Gustafson, W. I., Harley, R. A., He, S., Hemming, B., Hogrefe, C., Huang, H.-C., Hunt, S. W., Jacob, D. J., Kinney, P. L., Kunkel, K., Lamarque, J.-F., Lamb, B., Larkin, N. K., Leung, L. R., Liao, K.-J., Lin, J.-T., Lynn, B. H., Manomaiphinoon, K., Mass, C., McKenzie, D., Mickley, J., O'Neill, M., Nolte, C., Pandis, S. N., Racherla, P. N., Rozenweig, C., Russsel, A. G., Salathe, E., Steiner, A. L., Tagaris, E., Tao, Z., Tonse, S., Wiedinmyer, C., Williams, A., Winnser, D. A., Woo., A.-H., Wu, S., and Wubbles, D. J.: A preliminary synthesis of modeled climate change impacts on U.S. regional ozone concentrations, Bull. Amer. Met. Soc., 90, 1843-1863, doi:10.1175/2009BAMS2568.1, 2009.
Wild, O. and Akimoto, H.: Intercontinental transport of ozone and its precursors in a three-dimensional CTM, J. Geophys. Res., 106, 27729-27744, 2001.

Young, P. J., Arneth, A., Schurgers, G., Zeng, G., and Pyle, J. A.: The $\mathrm{CO}_{2}$ inhibition of terrestrial isoprene emission significantly affects future ozone projections, Atmos. Chem. Phys., 9, 27932803, doi:10.5194/acp-9-2793-2009, 2009.

Yu, H., Remer, L. A., Chin, M., Bian, H., Kleidman, R. G., and Diehl, T.: A satellite-based assessment of transpacific transport of pollution aerosol, J. Geophys. Res., 113, D14S12, doi:10.1029/2007JD009349, 2008.

Zhang, H., Feng X., Larssen T., Qiu G., and Vogt R. D.: In inland China, rice, rather than fish, is the major pathway for methylmercury exposure, Environ. Health Persp., 118, 1183-1188, 2010.

Zhang, L., Jacob, D. J., Boersma, K. F., Jaffe, D. A., Olson, J. R., Bowman, K. W., Worden, J. R., Thompson, A. M., Avery, M. A., Cohen, R. C., Dibb, J. E., Flock, F. M., Fuelberg, H. E., Huey, L. G., McMillan, W. W., Singh, H. B., and Weinheimer, A. J.: Transpacific transport of ozone pollution and the effect of recent Asian emission increases on air quality in North America: an integrated analysis using satellite, aircraft, ozonesonde, and surface observations, Atmos. Chem. Phys., 8, 6117-6136, doi:10.5194/acp-8-6117-2008, 2008.

Zhang, R., Li, G., Fan, J., Wu, D. L., and Molina, M. J.: Intensification of Pacific storm track linked to Asian pollution, PNAS, 104, 5295-5299, 2007.

Zhang, Y., Hemperly, J., Meskhidze, N., and Skamarock, W. C.: The Global Weather Research and Forecasting (GWRF) Model: Model Evaluation, Sensitivity Study, and Future Year Simulation, Atmos. Clim. Sci., 2, 231-253, doi:10.4236/acs.2012.23024, 2012a.

Zhang, Y., Karamchandani, P., Glotfelty, T., Streets, D. G., Grell, G., Nenes, A., Yu, F., and Bennartz, R.: Development and initial application of the global-through-urban weather research and forecasting model with chemistry (GU-WRF/Chem), J. Geophys. Res., 117, D20206, doi:10.1029/2012JD017966, 2012b. 